\title{
KONTROVERSI HADITS-HADITS MENANGISI MAYAT DALAM PERSPEKTIF MUKHTALIF HADITS
}

\author{
Arif Wahyudi \\ Jurusan Syariah STAIN Pamekasan, Jl Raya Panglegur km. 04 \\ Pamekasan, email: ariyos.wahyudi@yahoo.com
}

\begin{abstract}
Abstrak
Pertentangan antara hadits-hadits tentang menangisi mayit seringkali berdampak langsung kepada masyarakat akar rumput, sehingga sekedar menitikkan air mata karena keluarganya meninggal akan membuat yang lain menghardik dengan alasan bahwa si mayit akan disiksa di dalam kubur ketika ada yang menangis atau si mayit akan menjadi hantu. Pertentangan dalam masalah ini akan coba penulis kaji dan selesaikan dengan metode Mukhtalif Hadits. Ilmu Mukhtalif Hadits merupakan ilmu yang membahas pertentangan hadits dengan hadits lain, dengan al-Qur'an, logika dan fakta, baik pertentangannya secara zhahir atau hakiki. Hal ini senada dengan cakupan pembahasan kitab-kitab tentang mukhtalif hadits, diantaranya Tàwîl Mukhtalif al-Hadîts karya Abî Muhammad Abdullah ibn Muslim Qutaibah (213-276 H). Secara esensi, pertentangan antara satu hadits dengan yang lain hanyalah pada zhahirnya dan tidak bersifat hakiki, mengingat keseluruhannya bersumber dari Allah swt.

\section{kata Kunci}

Kontroversi, Menangisi Mayit, Mukhtalif Hadits
\end{abstract}

\section{Pendahuluan}

Dalam sejarahnya, hadits nabawi belum dibukukan dan ditulis secara massal pada masa Nabi saw. Secara umum, saat itu pengajaran dan periwayatan hadits dilakukan dengan lisan dan hafalan dan sedikit sekali dari sahabat yang menulis hadits, itu pun atas inisiatif pribadi. Seluruh potensi umat Islam saat itu hanya tertuju pada bagaimana menjaga kemurnian al-Qur'an 
dengan cara mendokumentasikan lewat tulisan maupun hafalan. Dengan sejarah yang demikian, tak heran jika mayoritas hadits merupakan khabar ahad. ${ }^{1}$ Oleh karena itu kajian hadits selalu dari dua sisi, yaitu tsubût dan dalâlah. Tsubût terkait benar tidaknya hadis tersebut berasal dari Nabi saw. atau tidak. Sedangkan dalâlah terkait dengan makna yang ditunjukkan oleh suatu hadits yang telah dinyatakan tidak masalah dalam tsubûtnya.

Dalam memahami hadits ada saja persoalan yang akan dihadapi, terkadang dalam tsubûtnya tidak terdapat masalah namun dalam dalâlahnya terjadi pertentangan antara satu hadis dengan lainnya. Pertentangan antara nash ini menurut Muhammad al-Madanî merupakan salah satu sebab yang melatarbelakangi terjadinya perbedaan pendapat dalam fikih. ${ }^{2}$ Untuk mengatasi pertentangan itu ulama berusaha untuk mencari penyelesaiannya, maka lahirlah suatu ilmu yang dikenal dengan ilmu Mukhtalif Hadits, dan dalam ilmu Ushul dikenal dengan ta'ârudh al-adillah.

Secara umum, Ilmu Mukhtalif Hadits menurut ulama ialah ilmu yang membahas hadits-hadits yang bertentangan atau berlawanan kemudian pertentangan itu coba dihilangkan atau dikompromikan antara keduanya, sebagaimana membahas hadits-hadits yang sulit dipahami dengan cara menghilangkan kesulitannya dan menjelaskan hakekat maknanya. ${ }^{3}$

Dari beberapa hadits yang dikategorikan bertentangan, hadits-hadits tentang menangisi mayat salah satu yang secara

\footnotetext{
${ }^{1}$ Hadits yang tidak memenuhi syarat mutawatir, yang memberi faedah ilmu nazharî, yaitu ilmu pembahasan dan penelitian lanjutan untuk memastikan kebenarannya (mutawatir: hadits yang diriwayatkan minimal 10 rawi pada setiap generasinya). Lihat Mahmûd Thahhân, Taisîr Musthalâh al-Hadîts (Beirut: Dâr al-Fikr, t.th), hlm. 19-21

2 Sebagaimana dikutip Huzaimah Tahido Yango, Pengantar Perbandingan Madzhab (Jakarta: Logos Wacana Ilmu, 1997), hm. 50

${ }^{3}$ Mula Nûr al-Dîn Abû al-Hasan al-Qârî, Syarh Nukhbah al-Fikr (Beirut; Dâr al-Arqâm, t.th), cet. I, jilid I, hlm. 162
} 
lahiriyah terlihat saling bertentangan. Satu kelompok hadits menyebut bahwa mayat akan disiksa karena tangisan keluarganya, kebanyakan hadits-hadits dari kelompok ini diriwayatkan oleh Umar bin Khatthab. Sementara kelompok yang lain menyebut bahwa Nabi saw. pernah menangis atas kematian anaknya Ibrahim, cucu dari salah seorang anak perempuan beliau, serta beberapa sahabat diantaranya Sa`ad bin Ubâdah. Dan kelompok hadits yang ketiga menyebut bahwa hadits tentang siksaan mayat karena tangisan keluarga bertentangan dengan al-Qur'an menurut Aisyah. Di antara hadits yang menjelaskan bahwa mayat akan disiksa karena tangisan keluarganya adalah:

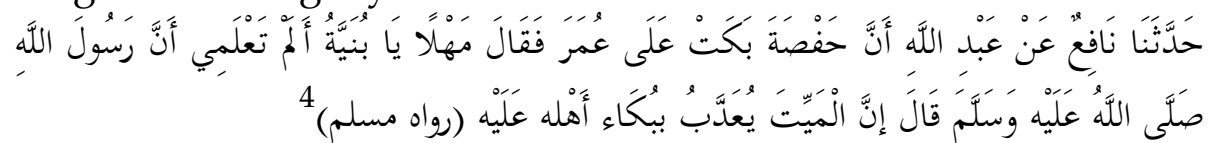
"Telah menceritakan kepada kami Nafi Dari Abdillah bin Umar bahwasanya Hafshah menangisi Umar, kemudian Umar berkata: Tenang wahai anakku, apakah engkau tidak tahu bahwa Rasulullah saw. pernah bersabda: Bahwasanya mayat akan diadzab karena tangisan keluarga atasnya" (HR. Muslim)

Adapun di antara hadits-hadits yang menjelaskan bahwa Nabi saw. pernah menangis atas meninggalnya keluarga atau sahabatnya terkandung pada hadits berikut:

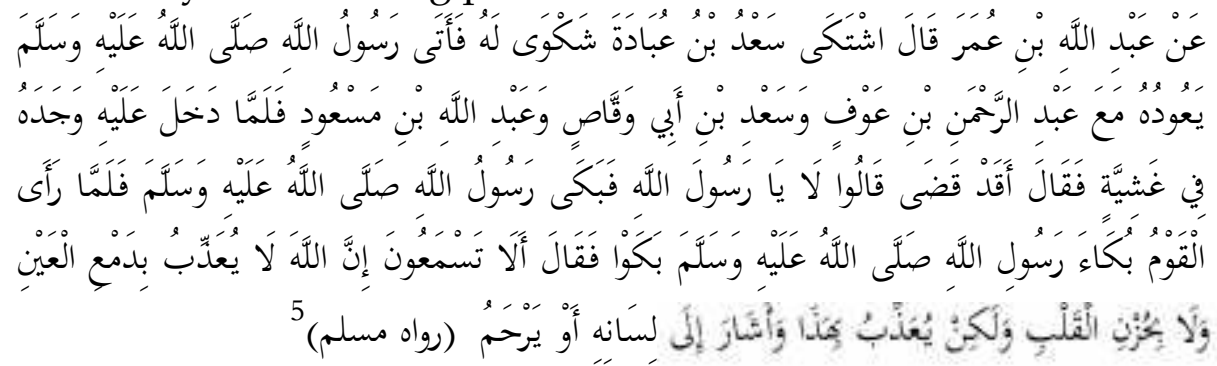

${ }^{4}$ Muslim bin al-Hajjaj, Shahîh Muslim (Beirut: Dâr al-Fikr, 1988), cet. I, Kitab: Janâiz, Bab: al-Mayyit Yu 'adzdzib bi Bukâ' Ahlih, hlm. 408

${ }^{5}$ Muslim, Shahîh Muslim, hlm. 407 
"Dari Abdullah bin Umar dia berkata: ketika Sa ad bin Ubadah sakit, Rasulullah saw. menjenguknya bersama Abdur Rahman bin Auf, Saad bin Abi Waqqash dan Abdullah bin Mas'ud, ketika beliau menemuinya beliau mendapatkan dia sedang dikerumuni keluarganya kemudian beliau bertanya: Apakah dia telah meninggal? Mereka (keluarga Saa'd) menjawab: Belum wahai Rasullullah. Kemudian Rasulullah saw. menangis, ketika mereka melihat tangisan rasul, mereka pun ikut menangis. Lalu rasul bersabda: Apakah kalian tidak mendengar bahwa Allah swt. tidak mengadzab karena air mata, tidak pula karena kesedihan hati, akan tetapi Allah swt. mengadzab dan merahmati karena ini, lalu beliau menunjuk ke lidahnya." (HR. Muslim)

Sedangkan hadits yang menyebut bahwa hadits tentang siksaan bagi mayit yang ditangisi bertentangan dengan al-Qur'an dijelaskan dalam hadits berikut:

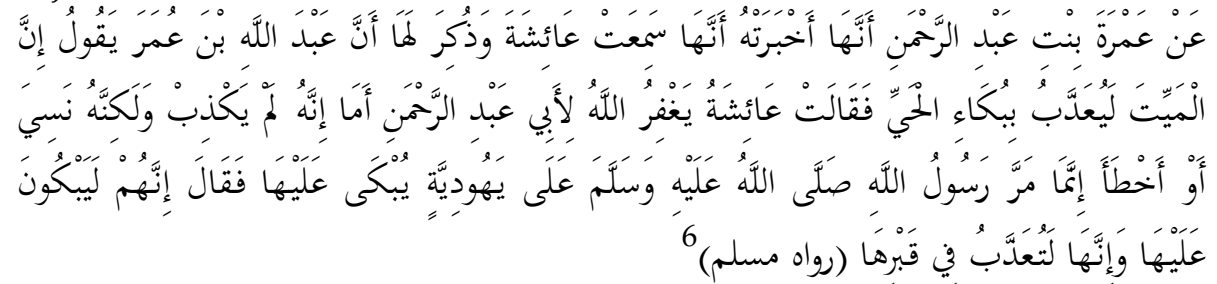

"Dari 'Amrah bint Abdurrahman, sesungguhnya dia memberitahukan padanya bahwa dia mendengar (hadits) disebutkan pada Aisyah bahwa Abdullah bin Umar berkata, "Sesungguhnya mayit akan diadzab dengan tangisan yang hidup". Kemudian Aisyah berkata, "Mudahmudahan Allah merahmati Abu Abdurrahman, sesungguhnya dia tidak berdusta akan tetapi dia lupa atau keliru, sesungguhnya Rasul saw. lewat di hadapan perempuan Yahudi (meninggal) yang sedang ditangisi, kemudian Rasul saw. bersabda, "Sesungguhnya mereka (keluarga perempuan Yahudi yang meninggal) menangisinya, sedangkan dia akan diadzab di kuburnya". (HR. Muslim)

Kitab hadits secara kuantitas sangat banyak, dengan tenaga dan waktu yang terbatas, rasanya sangat sulit untuk melacak

${ }^{6}$ Muslim, Shahîh Muslim, kitab: al-Janâ'iz, bab: al-Mayyit Yu’addzib bi Bukâ' Ahlih `Alaih Jilid 1, hal. 411 
dan mengumpulkan hadits terkait tema tertentu pada seluruh kitab hadits. Oleh karena itu, maksud dari hadits-hadits menangisi mayat pada judul penelitian ini, ialah hadits-hadits dengan tema tersebut yang terdapat dalam Kutub al-Sittah yaitu Shahîh al-Bukhârî, Shahîh Muslim, Sunan Ab̂̂u Daud, Sunan alTirmidzî, Sunan al-Nasầi dan Sunan Ibn Mâjah.

Pertentangan antara dua kelompok hadits menangisi mayat di atas, nyatanya berimbas langsung maupun tidak langsung di kalangan masyarakat akar rumput. Sekedar menitikkan air mata karena salah satu keluarga meninggal tak jarang akan mendapat hardikan dari yang lain, dengan alasan si mayat akan disiksa dalam kubur yang mengakibatkan ruhnya gentayangan. Apalagi jika ada yang mencoba mencium atau menengok jenazah sambil menangis, maka seketika akan banyak orang meminta agar airmatanya tidak mengenai jenazah, karena mereka percaya jika air mata mengenai jenazah maka si jenazah akan jadi din dedin. ${ }^{7}$

Realita yang terjadi pada masyarakat akar rumput tersebut membuat penulis semakin terdorong meneliti masalah ini untuk mengetahui bagaimana konstruksi hukum sesungguhnya dari hadits-hadits menangisi mayat dengan analisa mukhtalif hadits, terlebih kajian tema ini dengan analisa mukhtalif hadits tidak pernah dijumpai oleh penulis sebelumnya.

\section{Konsep Mukhtalif Hadits}

\section{A. Definisi Mukhtalif Hadits}

\section{Dari Segi Bahasa}

Mukhtalif hadits tersusun dari dua kata yaitu: مختلف dan dengan kasrah pada huruf J J J لف .حديث

\footnotetext{
${ }^{7}$ Din dedin: makhluk jadi-jadian/ siluman
} 
kata اختلافا - menurut Ibn Manzhur8 bermakna belakang dan merupakan lawan kata dari قدام احتام (حد)

Adapun hadits (حديث) secara bahasa merupakan kata benda dari (تحديث) yang berarti pembicaraan. Belakangan Ibn Hajar berpendapat bahwa kata hadits dapat pula bermakna baru, dia menjadikannya sebagai lawan kata dari qadim. Dengan demikian qadim adalah al-Qur'an sedang hadits adalah sabda Nabi saw., dan hadits ini telah menjadi nama bagi segala sesuatu yang disandarkan kepada Nabi saw. baik perkataan, perbuatan, persetujuan, sifat akhlak maupun sifat fisik. ${ }^{9}$

\section{Dari Segi Istilah}

Ulama berbeda pendapat mengenai definisi ilmu Mukhtalif Hadits baik lafadh maupun makna, di sini penulis akan mencantumkan beberapa definisi atau yang mendekatinya, sebagaimana berikut:

Imam Syafi'i mengatakan bahwa dua hadits tidak dapat dikatakan ikhtilaf (bertentangan) selama ada sisi yang memungkinkan kandungan keduanya dapat berlaku, sesungguhnya mukhtalif itu jika kandungannya tidak dapat berlaku kecuali dengan gugurnya yang lain. Seperti dua hadits tentang satu perkara, yang satu menghalalkan dan yang lain mengharamkan. ${ }^{10}$

al-Nawawi mengatakan bahwa dua hadits yang zhahirnya saling bertentangan dan dapat dikompromikan di antara keduanya, atau dikuatkan salah satunya. ${ }^{11}$

\footnotetext{
${ }^{8}$ Muhammad bin Makram bin Manzhur al-Afriqî al-Mishrî (selanjutnya disebut Ibn Manzhur), Lisân al-`Arab (Beirut: Dâr Shâdir, t.th.), cet, I, Jilid IX, hlm. 82

${ }^{9}$ Mahmud Tahhân, Taisîr Musthalah al-Hadîts (Beirut: Dâr al-Fikr, t.th), hlm. 14

${ }^{10}$ Muhammad bin Idrîs al-Syâfi i Abu Abdullah (selanjutnya disebut Imam Syafi i), al-Risalah (Beirut: Dâr al-Kutub al-'Ilmiyah, t.th.), hlm. 342

${ }^{11}$ Ibn Syaraf al-Nawâwî, Taqrîb 'Ulûm al-Hadîts (dengan catatan kaki Tadrîb al-Râwî) (al-Madinah: al-Maktabah al-'Ilmiyah, 1972), cet. II, jilid II, hlm. 197
} 
Ibn Hajar mengatakan bahwa hadits maqbul yang tidak bertentangan dengan hadits yang lain maka ia dapat dijadikan hujjah. Jika bertentangan dengan hadits lain yang juga maqbul dan terdapat sisi yang memungkinkan untuk dikompromikan, maka dia mukhtalif hadits. ${ }^{12}$

Menurut Syaraf al-Qudhât, mukhtalif hadits adalah "ilmu yang membahas pertentangan hadits dengan hadits lain, dengan al-Qur'an, logika dan fakta, baik pertentangannya secara zhahir atau hakiki."13

Jika dicermati, definisi-definisi di atas mengandung beberapa poin tentang mukhtalif hadits, sebagaimana berikut:

a. Mukhtalif Hadits mengharuskan pertentangannya terjadi antara hadits dengan hadits lainnya dan tidak mencakup pertentangan hadits dengan ayat, logika dan lain-lain. Padahal faktanya dalam karya ulama tentang mukhtalif hadits, pertentangan hadits dan ayat juga dibahas.

b. Pertentangan disyaratkan hanya pada zhahirnya, sebagaimana dalam definisi al-Nawawi dan yang mengikutinya. Meskipun secara faktual, pertentangan terjadi secara hakiki pada hadits-hadits yang teriwayat dalam kitabkitab dan tentu saja pertentangan bukan terjadi di sumbernya yaitu Nabi saw.

c. Sebagian yang lain juga mensyaratkan pertentangan harus bersifat hakiki dan tidak mungkin untuk dikompromikan, sebagaimana dalam definisi Imam Syafi i.

d. Beberapa definisi menyebutkan solusi bagi dua hadits yang bertentangan, meskipun sesungguhnya tidak ada hubungan dengan definisi karena definisi hanya memberi batasan tentang suatu ilmu.

\footnotetext{
12 Abû al-Fadhl Ahmad bin Ali bin Muhammad bin Ahmad bin Hajar al'Asqalânî, Nukhbat al-Fikr fì Mushtalah Ahl al-Atsar (Beirut: Dâr Ihyâ' al-Turâts al-`Arabî, t.th), hlm. 58-59

${ }^{13}$ Syaraf al-Qudhât, `Ilm Mukhtalif Hadits; Ushîluh wa Qawầiduh (Amman: alJami'ah al-'Urduniyah, 2001), hlm. 7
} 
e. Disyaratkan pada dua hadits yang bertentangan dan berkualitas maqbul (dapat dijadikan hujjah syar`i)

Dari beberapa uraian di atas penulis lebih cenderung setuju dengan definisi yang diungkapkan oleh Syaraf al-Qudhât. Hal ini senada dengan cakupan pembahasan kitab-kitab tentang mukhtalif hadits diantaranya Ta zwîl Mukhtalif al-Hadîts karya Abî Muhammad Abdullah ibn Muslim Qutaibah (213-276 H.). Dalam karyanya ini Ibnu Qutaibah mencoba mencari penyelesaian hadits-hadits yang dianggap saling berlawanan dengan hadits lainnya maupun hadits dengan al-Qur'an., pemahaman akal serta bertentangan dengan ke-Maha Suci-an

\section{B. Hakikat Mukhtalif}

Allah swt. ${ }^{14}$

Secara asal, tidak terdapat pertentangan di antara dalil-dalil syara', baik hadits dengan hadits atau hadits dengan al-Qur'an selama hadits tersebut merupakan hadits shahih dalam penyandarannya kepada Nabi saw. kecuali satu hadits merupakan nâsikh shârih 15 bagi hadits yang lainnya. Hal itu dikarenakan seluruh nash syara' baik al-Qur'an maupun hadits terbebas dari perbedaan dan pertentangan, mengingat sumber dari nash-nash tersebut satu yaitu Allah swt., mustahil hukum yang bersumber dariNya bertentangan antara satu dengan yang lain. ${ }^{16}$ Pertentangan antara dalil syara` tersebut pada hakikatnya hanya pada zhahirnya, bukan pada inti permasalahannya. Allah swt. berfirman dalam beberapa ayatnya: "Dan tiadalah yang diucapkannya menurut hawa nafsu, ucapannya itu tiada lain hanyalah wahyu yang diwahyukan (kepadanya)". (QS. al-Najm: 3-4) Ibn Qayyim berpendapat bahwa tidak terdapat pertentangan di antara hadits shahih, jika terjadi pertentangan

14 Muhammad bin Abdullah bin Muslim Qutaibah, Ta`wîl Mukhtalif al-Hadîts (Beirut: Dâr al-Isyrâq, 1989), cet. I, hlm. 1-14

15 Terdapat penjelasan syara', bahwa suatu hadits atau ayat merupakan penghapus bagi hadits atau ayat lainnya

16 Abd al-Majîd Bairûm, Ikhtilâf Riwâyât al-Hadits wa Atsaruh fî Ikhtilâf alFuqahâ' (Amman: al-Jami'ah al-Urduniyah, 1990), hlm. 166 
maka dipastikan salah satunya bukan merupakan sabda Rasulullah saw. Seorang periwayat mungkin saja keliru meskipun dia tsiqah (dapat dipercaya) atau salah satu hadits merupakan nâsikh hadits lainnya bagi yang berpendapat bahwa nasikh mansukh terjadi dalam nash syar'i atau pertentangan terjadi berdasarkan pemahaman seseorang bukan pada dzat sabda Nabi saw. itu sendiri. ${ }^{17}$ Ibn Huzaimah mengatakan bahwa tidak terdapat hadits yang saling bertentangan dengan hadits lain dari segala sisi, jika engkau mendapatkan satu pertentangan mengenainya maka datanglah padaku agar aku dapat mengkompromikan di antara keduanya. Oleh karena itu jumhur bersepakat bahwa tidak ada pertentangan secara hakiki di antara hadits nabawi baik secara qath $\hat{\imath}$ atau zhannî. ${ }^{18}$

\section{Syarat-Syarat Mukhtalif}

Pertentangan antara hadits dengan hadits lainnya menurut Abd al-Majid al-Bairum ${ }^{19}$ tidak dapat terwujud kecuali telah memenuhi beberapa hal berikut:

a. Pertentangan terjadi dalam satu konteks permasalahan, jika pertentangan pada dua konteks yang berbeda maka keduanya tidak dapat dianggap pertentangan. Seperti, seorang laki-laki dituntut untuk memuliakan isterinya namun di sisi lain seorang anak harus menghormati ibunya,

b. Pertentangan antara dua hukum atau madlûl, hukum yang terkandung dalam dua hadits yang saling bertentangan salah satunya menunjukkan keharaman dan yang lain menunjukkan kehalalan,

c. Kedua hadits yang bertentangan sama dalam kualitas,

\footnotetext{
17 Ali Nâif Baqâ'̂̀, al-Ijtihâd fì 'Ilm al-Hadits wa Atsaruh 'alâ al-Figh al-Islâmî (Beirut: Dâr al-Basyâ'ir al-Islâmiyah, 1998), hlm. 341-342

18 Abd al-Majîd Muhammad Isma'îl al-Sausuwah, Manhâj al-Taufíq wa alTarjîh bain Mukhtalif al-Hadîts wa Atsaruh fî Fiqh al-Islâmî (Kairo: Jami ah alQâhirah, 1992), hlm 71

${ }^{19}$ Abd al-Majîd Bairûm, Ikhtilâf Riwâyât al-Hadits, hlm. 167
} 
d. Pertentangan terjadi pada satu keadaan, misalnya hadits tentang celaan bagi saksi yang tidak jujur dengan hadits tentang pujian bagi saksi-saksi yang jujur dan memberi kesaksian sesuai keadaan.

\section{Sebab-sebab Mukhtalif}

Pertentangan antara hadits dengan hadits lainnya secara umum dilatarbelakangi oleh kesalahan periwayat, baik pada hafalan dan periwayatannya atau karena keterbatasan pemahaman terhadap hadits-hadits terkait. Berikut ini beberapa sebab dari terjadinya pertentangan di antara hadits:

a. Sebab-Sebab Ikhtilaf Zhahiri

1) Tidak memiliki pemahaman yang baik mengenai hadits Nabi saw. sehingga mudah mengatakan bahwa suatu hadits bertentangan dengan hadits lain atau ayat.

2) Terbatasnya akal manusia, tidak semua hal dapat diketahui dan dipastikan oleh akal manusia, sebagian hal justru hanya dapat diduga dan dikira. Keterbatasan itulah yang menjadi penyebab beberapa hadits dianggap bertentangan padahal nash syar $i$ yang shahih tidak mungkin bertentangan karena seluruhnya bersumber dari Allah swt. ${ }^{20}$

b. Sebab-Sebab Ikhtilaf Hakiki

Yang dimaksud dengan pertentangan "hakiki" di sini pada hakikatnya tidaklah hakiki, karena pertentangan tidak terjadi pada sumbernya (dari Nabi saw.) kecuali pada nasakh shârih, berikut ini sebab-sebab ikhtilaf hakiki:

1) Nasakh dalam hukum syara', al-nâsikh selalu bertentangan dengan mansûkh, baik nasakh sharîh atau ghair sharîh. Akan tetapi nasakh yang terjadi mayoritas nasakh ghair sharih yang diketahui dari sejarah munculnya masing-masing hadits.

2) Perbedaan rawi dalam menghafal, misalnya para sahabat bertanya suatu perkara kepada Nabi saw. kemudian Nabi

${ }^{20}$ Syaraf al-Qudhât, 'Ilm Mukhtalif Hadits, hlm. 13 
saw. menjawabnya dan mereka menghafal sabda Nabi saw, yang merupakan jawaban atas pertanyaan tersebut, lalu mereka lupa dengan pertanyaan tersebut dan memahami hadits sesuai dengan keumumannya, pada akhirnya kelupaan sebab hukum itu menjadi sebab pertentangannya dengan hadits lain. Padahal pertentangan tersebut tidak akan pernah terjadi jika pertanyaan dan sebab munculnya suatu hukum diketahui dan masing-masing hadits dapat dipahami berdasarkan proporsinya. Menurut Imam Syafi i, terkadang seorang periwayat meriwayatkan hadits yang merupakan jawaban atas suatu persoalan tanpa mengetahui akar masalah $^{21}$.

3) Perbedaan Cara Rawi dalam Meriwayatkan Hadits

Perbedaan ini biasa terjadi ketika seorang rawi meriwayatkan hadits secara sempurna sedangkan yang lainnya meriwayatkan dengan ringkas, kemungkinan hal ini dilakukan karena si periwayat hanya mendengar hadits dalam bentuk yang ringkas tersebut atau karena sebab lainnya. Kemudian kedua hadits tersebut tampak bertentangan karena sebagian diriwayatkan secara sempurna dan yang lain secara ringkas. Menurut Imam Syafi i, terkadang Rasulullah saw. ditanya tentang suatu permasalahan, beliau pun menjawab sekedar pada masalah yang ditanyakan kemudian periwayat menerima riwayat tidak lengkap dan meriwayatkan sebagian tanpa sebagian

\section{E. Metode Penyelesaian Mukhtalif Hadits}

$$
\text { yang lain. } .^{22}
$$

Ulama berbeda pandangan mengenai urutan pada proses penyelesaian hadits-hadits atau dalil syara` yang bertentangan. Menurut Hanafi, urutannya adalah sebagai berikut: 1. al-Nasakh, 2. al-Tarjîh, 3. al-Jam 'u, 4. al-Tawaqquf/al-Tashâquth. Nampaknya urutan ini dibuat oleh Imam Hanafi untuk pertentangan yang

${ }^{21}$ al-Syâfi 1 î, al-Risâlah, hlm. 213.

22 al-Syâfi 1 î, Ikhtilâf al-Hadîts, hlm 18 
bersifat hakiki. Padahal menurut mayoritas ulama, pertentangan di antara dalil-dalil yang shahih tidak mungkin terjadi karena seluruhnya bersumber dari Allah swt.

Imam Syafi i dan mayoritas ahli Hadits ${ }^{23}$ berpendapat tentang proses penyelesaian mukhtalif hadits, sebagaimana berikut:

1. al-Jam'u wa al-Taufiq, yaitu mencari titik pertentangan dan berusaha untuk mengkompromikannya.

2. Nasakh, metode ini tidak dapat digunakan kecuali telah terpenuhi syarat-syarat berikut ${ }^{24}$ :

a. Kedua dalil sama-sama shahih atau kuat,

b. Tidak terdapat nasakh sharîh,

c. Tidak dapat dikompromikan,

d. Diketahui mana hadits yang muncul lebih dahulu dan mana yang muncul belakangan.

3. al-Tarjîh, yaitu mengambil salah satu dalil dan meninggalkan yang lain karena keyakinan bahwa salah satu dalil terdapat kekeliruan di dalamnya. Cara ini dapat dilakukan apabila memenuhi syarat-syarat berikut ${ }^{25}$ ini:

a. Kedua dalil yang bertentangan sama-sama shahih atau kuat,

b. Tidak terdapat nasakh sharîh pada keduanya,

c. Tidak terdapat titik temu yang dapat mengkompromikan keduanya,

d. Sejajar dalam kualitas keshahihannya.

4. al-Tawaqquf/al-Tasâquth, yaitu tidak mengambil kedua dalil yang bertentangan, dengan syarat tidak dapat dipecahkan dengan seluruh bentuk penyelesaian baik kompromi, nasakh maupun tarjih. ${ }^{26}$

${ }^{23}$ Ibn Shalâh, Muqaddimah Ibn Shalâh, hlm. 170

24 Ibid. hlm. 60

${ }^{25}$ Syaraf al-Qudhât, Mukhtalif Hadîts, hlm. 25

26 Ibid. hlm. 27 


\section{Hadits-Hadits Seputar Menangisi Mayit}

Memahami (al-figh) dan mengkritisi (al-naqd) adalah dua hal yang pemberangkatannya berbeda. Memahami hadits berangkat dari persepsi, suatu hadits yang sedang dipahami otentik berasal dari Nabi saw. Kritik berangkat dari prakonsepsi netral atau kecurigaan terhadap keshahihan sebuah hadits. Mukhtalif Hadits adalah bagian dari pemahaman hadits yang secara zhahir bertentangan, maka penjabaran tentang sanad hadits dan kualitas masing-masing perawi dirasa tidak diperlukan pada paparan data ini. Dari kajian awal, nampaknya tidak terdapat masalah pada sanad hadits yang akan dikaji, terlebih masing-masing kelompok yang bertentangan diriwayatkan oleh hampir seluruh mukharrij hadits. Kajian tentang sanad hadits baru akan dicantumkan, jika cara penyelesaian pertentangan hadits yang digunakan adalah "tarjih".

Setelah ditakhrij, terdapat dua pertentangan pada haditshadits tentang menangisi mayit; pertama, antara hadits-hadits "mayit diadzab karena tangisan keluarga atau orang yang masih hidup" dengan hadits-hadits yang menjelasan tangisan Nabi saw. atas kematian kerabat beliau. kedua, pertentangan antara hadits-hadits "mayit diadzab karena tangisan keluarga atau orang yang masih hidup" dengan "al-Qur'an" menurut pemahaman sayyidah Aisyah".

Berikut ini hadits-hadits tentang menangisi mayit, namun karena keterbatasan tempat maka akan disebutkan sebagiannya saja:

\section{Hadits-Hadits Tentang Mayit Diadzab Karena Tangisan Keluarga atau Orang Yang Masih Hidup}




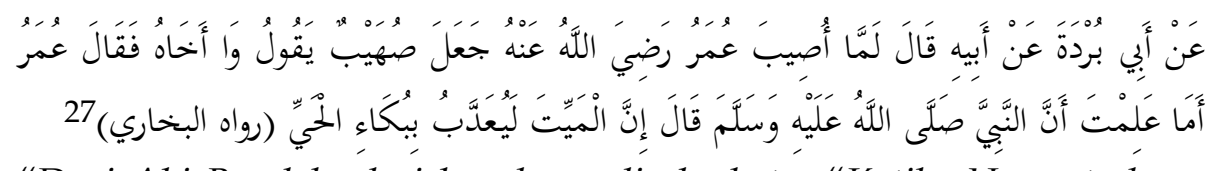

"Dari Abi Burdah, dari bapaknya dia berkata, "Ketika Umar terkena musibah (ditusuk), Shuhaib berkata, "Wahai Saudaraku, kemudian Umar berkata, "Sesungguhnya Nabi saw. bersabda, "Sesungguhnya mayit akan diadzab karena tangisan orang yang masih hidup". (HR. Bukhari)

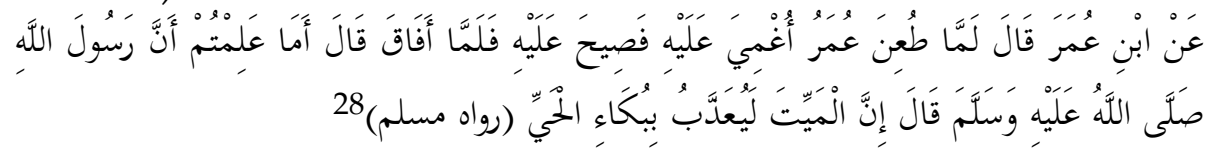

"Dari Ibn Umar dia berkata, "Ketika Umar ditusuk beliau tidak sadarkan diri (banyak orang menangis) dengan berteriak." Maka tatkala beliau sadar dia berkata, "Apakah kalian tidak tahu bahwasanya Rasul saw. bersabda "Sesungguhnya mayit akan diadzab karena tangisan orang yang masih hidup". (HR. Muslim)

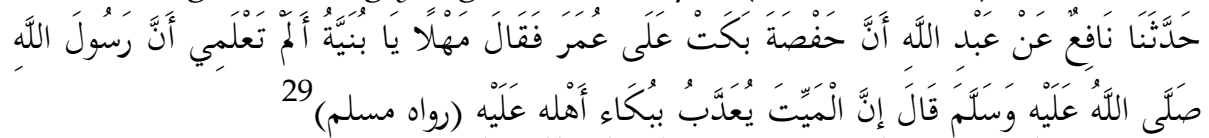

"Telah menceritakan kepada kami Nafi' dari Abdullah bahwa Hafshah menangisi ayahnya yaitu Umar bin Khaththab", maka Umar pun berkata, "Sabarlah anakku, apakah kamu tidak tahu bahwa Rasulullah shallallahu 'alaihi wasallam pernah bersabda, "Sesungguhnya mayit itu akan disiksa lantaran tangisan keluarganya atasnya". (HR. Muslim)

${ }^{27}$ Abu Abdillah Muhammad bin Ismâ'il al-Bukhâri, Shahîh al-Bukhârî (Beirut: Dâr al-Fikr, t.th.), kitab: al-Janâ'iz, bab: Qaul al-Nabî Yu’addzib al-Mayyit bi Bukâ'i Ahlih `Alaih, Jilid 1, hal. 224

${ }^{28}$ Abi al-Husain Muslim bin al-Hajjâj al-Qusyairî al-Naisâbûrî, Shahîh Muslim (Beirut: Dâr al-Fikr, 1988), cet. I, kitab: al-janâ'iz, bab: al-Mayyit Yu`addzib bi Bukâ; Ahlih `Alaih, Jilid 1, hal. 408.

${ }^{29}$ Muslim, Shahîh Muslim, kitab: al-Janâ'iz, bab: al-Mayyit Yu`addzib bi Bukâ; Ahlih `Alaih, Jilid 1, hlm. 408. 


\section{Hadits-Hadits Tentang Rasulullah saw. Menangis Karena Kematian Kerabat dan Sahabat Beliau}

a. Rasulullah Menangis Karena Kematian Puteri Beliau

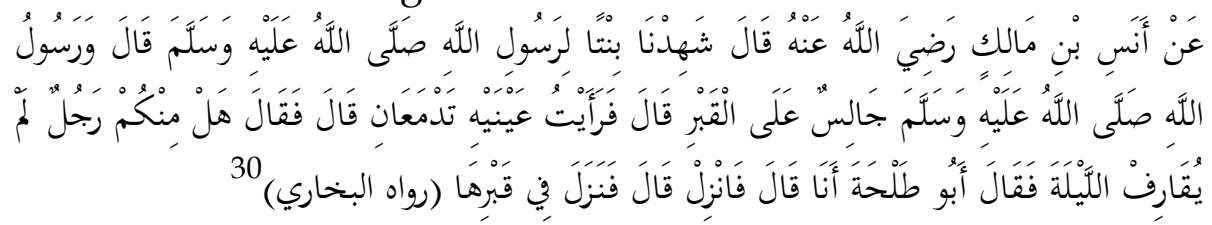

"Dari Anas bin Malik ra. dia berkata, "Kami menyaksikan jenazah putri Rasulullah saw, (Anas berkata melanjutkan cerita) dan nabi duduk di atas kubur, (Anas berkata melanjutkan cerita) dan aku melihat kedua mata beliau berlinang air mata, (Anas berkata melanjutkan cerita) kemudian Rasulullah saw. bersabda, "Apakah terdapat seorang laki-laki di antara kalian yang tidak melakukan dosa tadi malam?" Abu Thalhah berkata, "Aku (wahai Nabi), maka turunlah", lalu dia turun ke kubur puteri Beliau. (HR. Bukhari)

b. Rasulullah saw. Menangis Karena Kematian Anak Beliau Ibrahim

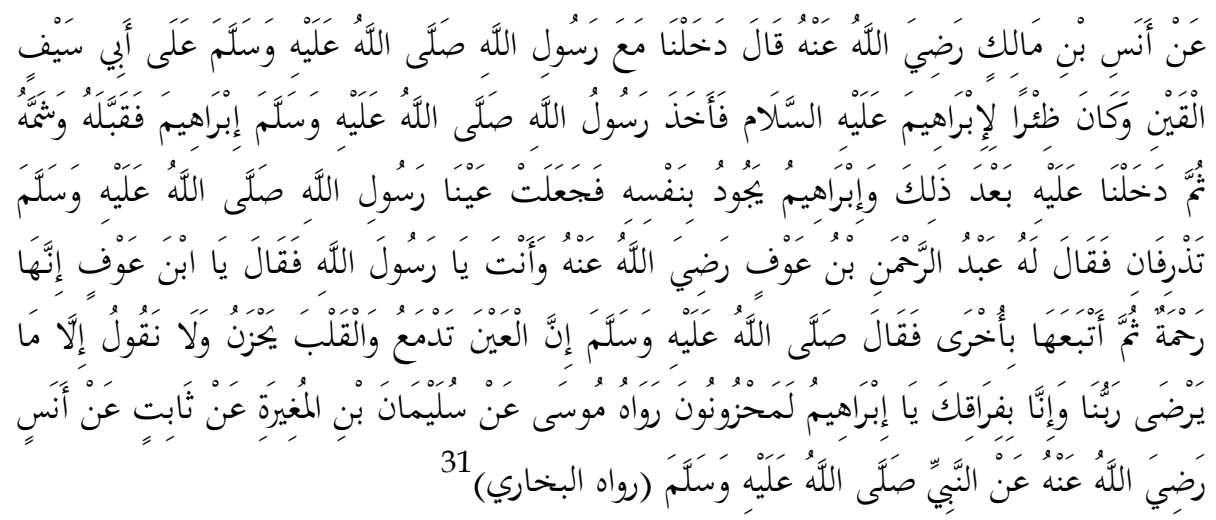

"Dari Anas bin Malik dia berkata, "Kami masuk bersama Rasul saw. ke rumah Abi Saif seorang tukang besi dan istrinya adalah perempuan

30 Al-Bukhârî, Shahîh al-Bukhârî, kitab: al-Janâ'iz, bab: Qaul al-Nabî Yu’addzib al-Mayyit bi Bukâ'i Ahlih `Alaih, Jilid 1, hlm. 223

31 al-Bukhârî, Shahîh al-Bukhârî, kitab: al-Janâ'iz, bab: Innâ Bika Lamahzûnîn, Jilid 1, hlm. 226. Lihat juga Muslim, Shahîh Muslim, kitab: al-Fadhấil, bab: Rahmatuh Lishabiyyîn wa li `Ail wa Tawâdhû`uh wa Fadhl Dzâlik, Jilid 2, hlm. 409 
yang menyusui Ibrahim (putra nabi saw.), kemudian Rasul saw. mengambil Ibrahim lalu menciumnya, kami masuk ke tempat (Ibrahim), dan Ibrahim dalam keadaan sakaratul maut. Sementara mata rasul saw. basah berlinangan air mata, (melihat hal itu) Abdurrahman bin Auf berkata, "Engkau, wahai Rasulullah (menangis)?" Rasul menjawab, "Wahai Ibn Auf, ini adalah rahmat". Kemudian beliau menjelaskan lagi, "Mata menangis, hati bersedih tapi kami tidak mengatakan apapun kecuali yang diridhai Allah, dan kami sangat bersedih atas kepergianmu, wahai Ibrahim". (HR. Bukhari)

c. Rasulullah Menangis Karena Kematian cucu Beliau

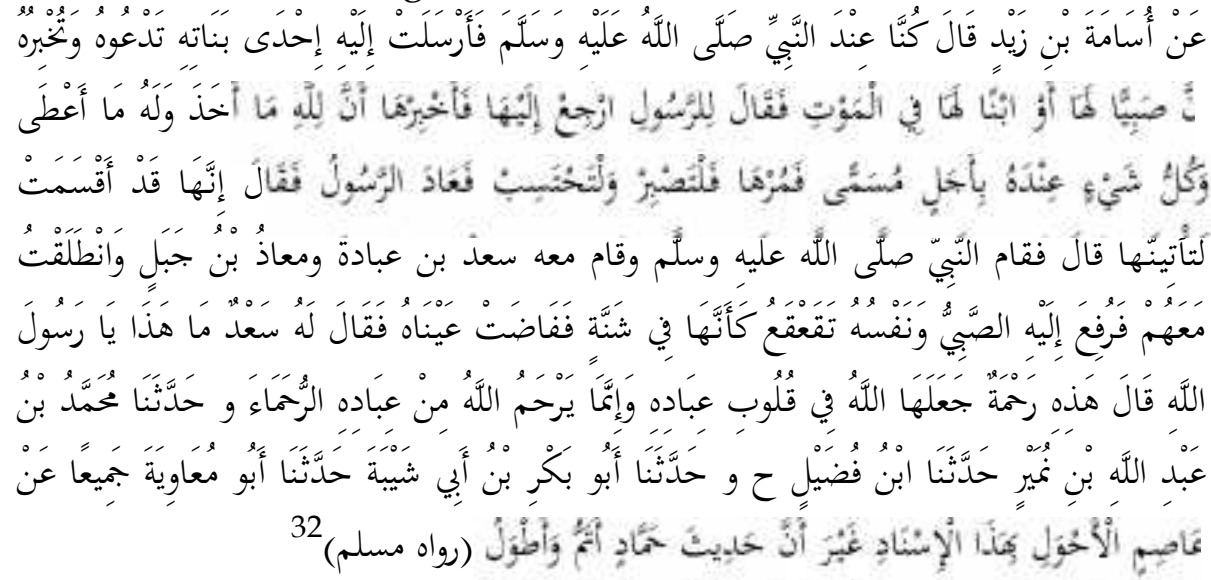

"Dari Usamah bin Zaid dia berkata, "Kami sedang berada di dekat Rasul saw. ketika salah seorang putri beliau mengirim utusan untuk memanggil beliau dan memberi kabar bahwa anak puteri beliau sedang menghadapi maut, lalu Rasul bersabda kepada utusan tersebut, "Kembalilah dan kabarkan kepadanya bahwa apa yang Allah ambil dan berikan adalah milikNya semata, segala sesuatu di sisiNya adalah

32 Muslim, Shahîh Muslim, kitab: al-Janâ'iz, bab: al-Bukâ' Ala al-Mayyit, Jilid 1, hlm. 406., lihat pula al-Bukhâri, Abu Abdillah Muhammad bin Ismầil, Shahîh al-Bukhârî, kitab: al-Tauhîd, bab: Inna Rahmah Allah Qarîb, Jilid 4, hlm. 288. Lihat juga di Ibn Mâjah, Sunan Ibn Mâjah (Beirut: Dâr al-Fikr, t.th.), kitab: Mâ Jâ’a fî al-Janâ'iz, bab: Mâ Jâ'a fî al-Bukâ' ’alâ al-Mayyit, Jilid 1, hlm. 506 
dengan batas waktu tertentu. Suruhlah dia bersabar dan mengharap pahala". Utusan itu kembali dan berkata, "Dia berjanji untuk memenuhi pesan-pesan itu". Lalu Nabi saw. berdiri diikuti Saad bi Ubadah dan Mu'adz bin Jabal. Akupun (Usamah bin Zaid) ikut berangkat bersama mereka. Kepada beliau anak dari putri beliau diserahkan dan jiwanya bergolak seperti berada dalam qirbah (tempat air) tua. Kedua mata Rasul saw. menitikkan air mata. Lalu Sa'ad bertanya, "Apa arti air mata itu, wahai Rasulullah?" Rasul menjawab, "Ini adalah rahmat (kasih sayang) yang diletakkan Allah dalam hati para hambaNya. Sesungguhnya Allah mengasihi para hambaNya yang pengasih". (HR. Muslim)

\section{Hadits-Hadits Tentang Mayit Diadzab Karena Tangisan Keluarga dan Pertentangannya Dengan al-Qur'an Menurut Pemahaman Aisyah}

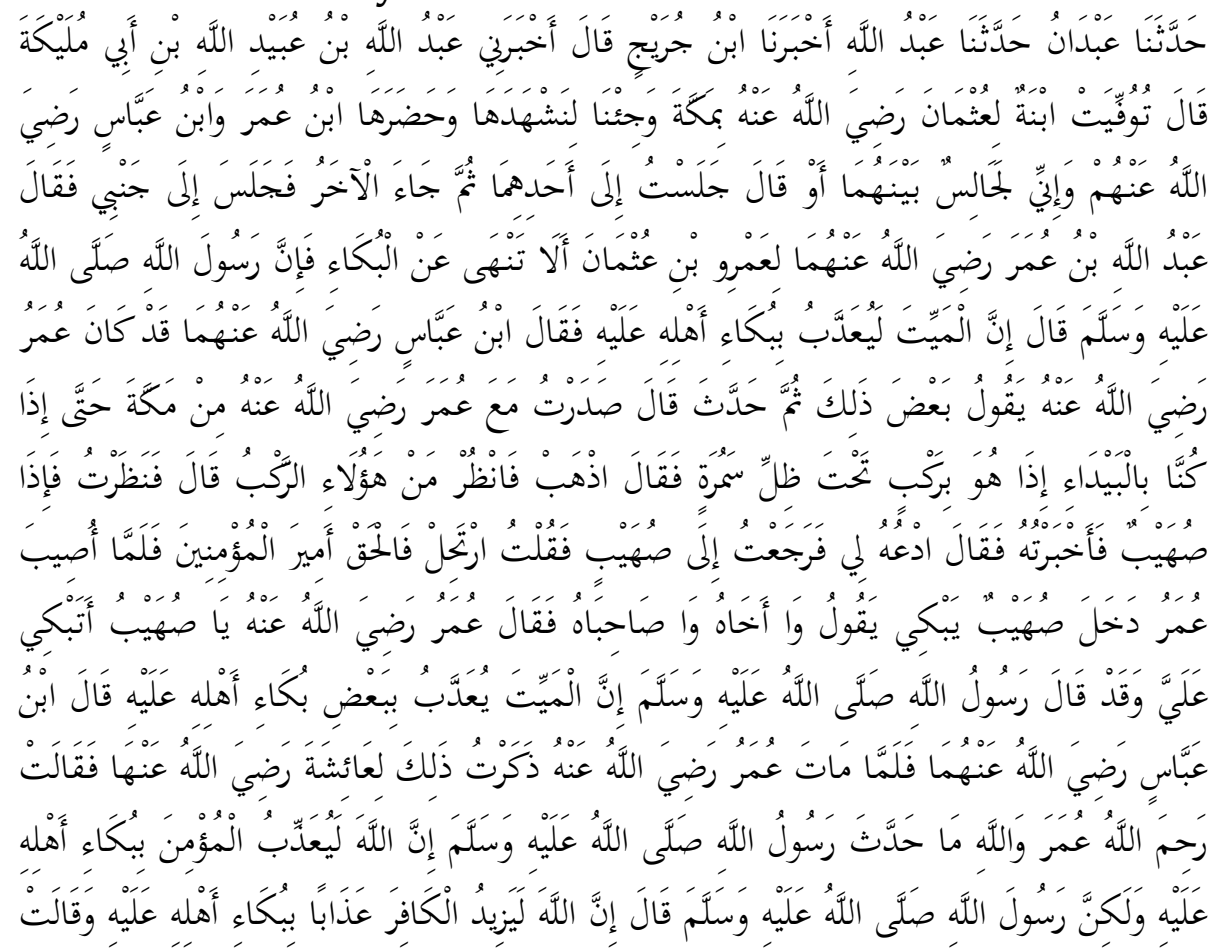




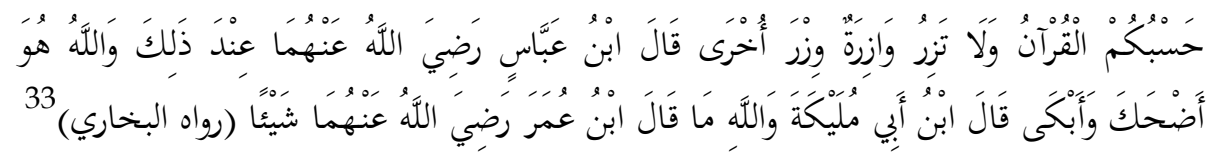

Telah menceritakan kepada kami 'Abdan, telah menceritakan kepada kami `Abdullah, telah mengabarkan kepada kami Ibn Juraij dia berkata, "Telah menceritakan kepadaku Abdullah bin Abdullah bin Abi Malikah dia berkata, "Telah wafat putri Utsman ra. di Makkah dan kami datang untuk menyaksikannya, Ibn Umar dan Ibn Abbas juga menghadirinya dan aku duduk di antara keduanya, atau dia berkata, "Aku duduk di samping salah satunya dan yang lain datang lalu duduk di sebelahku". Kemudian Abdullah bin Umar ra. berkata kepada Amr bin Utsman, "Tidakkah engkau berhenti dari menangis karena Rasul saw. bersabda, "Sesungguhnya mayit diadzab karena tangisan keluarganya". Lalu Ibn Abbas berkata, "Dalam hadits Umar diredaksikan dengan: Sebagian tangisan". Kemudian dia bercerita, "Aku pernah pergi bersama Umar dari Makkah, saat kami berada di padang pasir ada kafilah berteduh di bawah naungan pohon besar. Umar berkata, "Pergilah dan lihatlah siapa mereka itu!" Ibn Abbas berkata, "Maka aku melihatnya, ternyata dia adalah Shuhaib, akupun mengabarinya". Umar berkata: "Panggil dia kepadaku", lalu aku kembali ke Shuhaib dan berkata, "Pergilah dan bergabung dengan Amir al-mu 'minin". Ketika Umar tertimpa musibah, Shuhaib masuk sambil menangis dan berkata, "Wahai saudaraku, wahai sahabatku". Kemudian Umar ra. berkata, "Wahai Shuhaib, apakah engkau menangisiku, padahal Rasul saw. bersabda, "Sesungguhnya mayit akan disiksa karena tangisan keluarganya atasnya". Ibn Abbas berkata, "Ketika Umar telah wafat aku memberitahukan Aisyah ra. tentang hal itu". Lalu Aisyah berkata, "Mudah-mudahan Allah merahmati Umar, demi Allah, Rasul saw. tidak bersabda, "Sesungguhnya mayit akan disiksa karena sebagian tangisan keluarganya atasnya". Tetapi beliau bersabda, "Sesungguhnya Allah

33 al-Bukhârî, Shahîh al-Bukhârî, kitab: al-Janâ'iz, bab: Qaul al-Nabî Yu’addzib al-Mayyit bi Bukâ'i Ahlih `Alaih, Jilid 1, hlm. 223, lihat pula Muslim, Shahîh Muslim, kitab: al-Janâ'iz, bab: al-Mayyit Yu’addzib bi Bukâ' Ahlih 'Alaih, Jilid 1, hlm. 409, 411 
akan menambah adzab orang kafir dengan tangisan keluarganya atasnya". Ia berkata lagi, "Cukuplah bagi kalian al-Qur'an, "seseorang tidak menanggung dosa orang lain". Lalu Ibn Abbas berkata saat itu, "Dan Allah yang membuat orang tertawa dan menangis". Ibn Abi Mulaikah berkata, "Demi Allah, Ibn Umar tidak berkata sedikitpun". (HR. Bukhari)

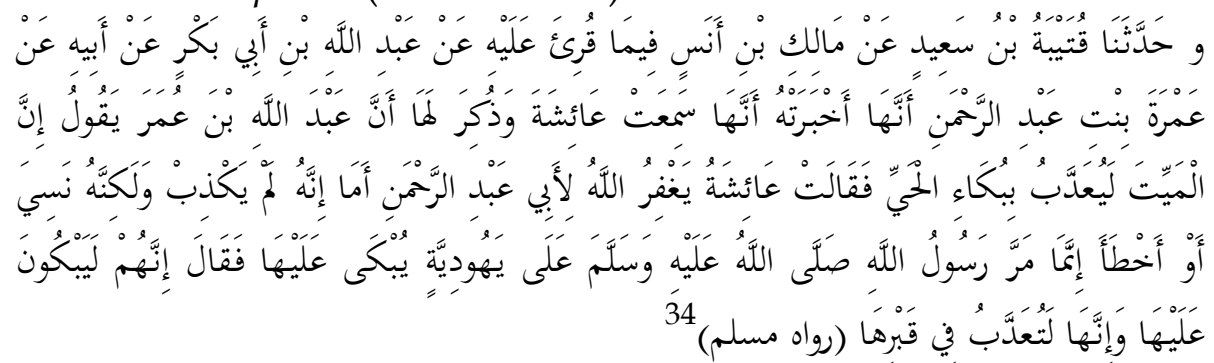

Telah menceritakan kepada kami Qutaibah bin Sa id dari Malik bin Anas tentang apa yang dibacakan kepadanya, dari Abdullah bin Abi Bakar, dari ayahnya, dari 'Amrah bint Abdurrahman, sesungguhnya dia memberitahukan padanya bahwa dia mendengar (hadits) disebutkan pada Aisyah bahwa Abdullah bin Umar berkata, "Sesungguhnya mayit akan diadzab dengan tangisan yang hidup". Kemudian Aisyah berkata, "Mudah-mudahan Allah merahmati Abu Abdurrahman, sesungguhnya dia tidak berdusta akan tetapi dia lupa atau keliru, sesungguhnya Rasul saw. lewat di hadapan perempuan Yahudi (meninggal) yang sedang ditangisi, kemudian Rasul saw. bersabda, "Sesungguhnya mereka (keluarga perempuan Yahudi yang

\footnotetext{
${ }^{34}$ Muslim, Shahîh Muslim, kitab: al-Janâ'iz, bab: al-Mayyit Yu`addzib bi Bukâ' Ahlih 'Alaih Jilid 1, hal. 411, lihat juga Abî 'Îsâ Muhammad bin 'Îsâ bin Saurah al-Tirmidzî, Sunan al-Tirmidzi (Beirut: Dâr al-Fikr, t.th.), kitab: alJanâ'iz `an Rasûlillâh, bab Mâ Jâ'a fî al-Rukhshah fî al-Bukâ' 'Alâ al-Mayyit, jilid 3, hlm. 328 - 329, lihat pula Al-Nasâ'î, Sunan al-Nasa'î bi Syarh al-Suyûthî wa al-Sindiy (Kairo: Dâr al-Hadîts, 1421 H/2000 M), kitab: al-Janâ'iz, bab: alNiyâhah `alâ al-Mayyit, Jilid 2, hlm. 443 - 444, lihat pula Abi Daud Sulaiman bin Asy'as al-Sijistânî, Sunan Abû Dâud (Beirut: Dâr al-Fikr, 1410 H/1990 M), cet. I, kitab: al-Janâ'iz, bab: fî al-Nauh, , Jilid 2 , hlm. 65, lihat pula Ibn Majah, hlm. 508
} 
meninggal) menangisinya, sedangkan dia akan diadzab di kuburnya. (HR. Muslim)

\section{Konstruksi Hukum Menangisi Mayit Perspektif Mukhtalif Hadits}

Hadits Nabi saw. adalah wahyu selain al-Qur'an yang diturunkan oleh Allah swt. kepada nabi Muhammad saw. Dengan demikian, tidak mungkin terdapat pertentangan secara hakiki antara satu hadits dengan lainnya atau satu hadits dengan al-Qur'an karena seluruhnya berasal dari satu sumber yaitu Allah swt. Apabila dicermati, beberapa kajian tentang mukhtalif hadits pada prinsipnya adalah merupakan suatu upaya untuk mencari titik temu (al-jam'u wa al-taufiq) antara hadits-hadits yang bertentangan dengan hadits lainnya, dengan al-Qur'an, logika dan fakta. Jika tidak dimungkinkan, barulah alternatif penyelesaian lain yang digunakan oleh para ulama yaitu nasakh dan jika tidak dapat diselesaikan dengan cara nasakh, cara lain yang digunakan adalah tarjih, jika tarjih pun tidak dapat dilakukan, upaya terakhir yang dapat digunakan adalah tawaqquf atau tasâquth. Metode penyelesaian dari hadits-hadits yang bertentangan tersebut sifatnya berjenjang sesuai dengan urutan yang dibuat ulama dan tidak mesti seluruhnya digunakan. Jika suatu pertentangan telah dapat diselesaikan dengan cara kompromi maka nasakh, tarjih dan tawaqquf tidak perlu digunakan.

1. Penyelesaian Pertentangan Antara Hadits Mayit Diadzab Karena Tangisan Keluarga dan Orang Yang Masih Hidup dengan Tangisan Rasul Atas Kematian Sanak Kerabatnya Menggunakan Metode Mukhtalif Hadits

Hadits Umar bin Khatthab dan Ibn Umar yang menjelaskan tentang "mayit akan diadzab karena tangisan keluarga", secara zhahir bertentangan dengan dua kelompok hadits yang telah dipaparkan di atas, salah satunya dengan hadits-hadits yang menunjukkan bahwa Rasulullah saw. menangis atas meninggalnya keluarga dan sahabat beliau. 
Dalam kajian Mukhtalif Hadits kedua kelompok hadits ini telah memenuhi syarat-syarat pertentangan sebagaimana berikut:

a. Pertentangan terjadi dalam satu permasalahan; kedua kelompok sama-sama terkait dengan masalah menangisi jenazah;

b. Pertentangan antara dua hukum atau madlul, dalam kajian ini satu kelompok hadits menjelaskan bahwa mayit diadzab karena tangisan keluarga atasnya, sedangkan hadits yang lain menjelaskan bahwa nabi saw. menangis atas kematian beberapa kerabatnya;

c. Pertentangan dalam satu keadaan. ${ }^{35}$

Berikut ini penyelesaian pertentangan antara haditshadits tentang "mayit diadzab karena tangisan keluarga atasnya" dengan hadits-hadits yang menjelaskan "nabi saw. menangis atas kematian beberapa kerabatnya" dengan metode Mukhtalif Hadits:

\section{a. Penyelesaian Dengan al-Jam ‘u wa al-Taufiq}

Cara paling utama yang dapat digunakan dalam menyelesaikan pertentangan adalah الجمع والتوفيق (kompromi), salah satunya dengan memaknai hadits atau lafazh-lafazh di dalamnya sesuai dengan porsi yang dikandung. ${ }^{36}$ Kata paling sentral dan paling penting untuk diketahui maknanya pada hadits tentang "Mayit diadzab karena tangisan keluarga" adalah البكاء البكاء secara bahasa memiliki arti menangis. Menangis di sini dapat berupa sekedar menitikkan air mata tanpa bersuara maupun menangis dengan bersuara. ${ }^{37}$ Yang menjadi pertanyaan adalah apakah kata al-bukấ dalam hadits di

\footnotetext{
${ }^{35}$ Abd al-Majîd Bairûm, Ikhtilâf Riwâyât al-Hadits, hlm. 167

${ }^{36}$ Memaknai hadits sesuai dengan porsinya adalah salah satu tekhnik dalam menjama` hadits, lihat Hakîmah Hafîzhî, Mukhtalif al-Hadîts, hlm. 46-56

${ }^{37}$ Ibn Manzhûr, Lisân al- 'Arab (Beirut: Dâr Shâdir, t.th.), cet, I, Jilid IX, Jilid. I, hlm. 34
} 
atas mencakup keduanya atau salah satunya? Ulama ${ }^{38}$ berpendapat bahwa kata البكاء dalam hadits memiliki arti النياء yaitu meratap (sambil bersuara dan berbicara) ${ }^{39}$. Allah swt berfirman:

"Dan sesungguhnya setiap kali aku menyeru mereka (kepada iman) agar engkau mengampuni, mereka memasukkan jari-jari mereka ke dalam telinganya dan menutupkan bajunya (ke mukanya) dan mereka tetap (mengingkari) dan menyombongkan diri dengan sangat". (QS. Nuh: 7)

Tidak masuk akal apabila seseorang menutup telinga dengan seluruh jari mereka, pada ayat di atas, Allah swt. menggunakan redaksi umum tapi maksudnya khusus, meredaksikan dengan الأصابع yakni jari-jari (bentuk plural) tapi maksudnya adalah الإصبع yakni jari (bentuk tunggal). Dalam redaksi hadits di atas pun demikian adanya, menggunakan redaksi umum البكاء tapi maksudnya adalah khusus النياحة. Penggunaan redaksi semacam itu sangat lazim terjadi, dan redaksi hadits di atas pun telah sesuai dengan kaidah-kaidah balaghah dalam bahasa Arab.

Menurut al-Nawawi, ulama bersepakat terlepas dari perbedaan madzhab mereka bahwa maksud dari kata البكاء pada hadits di atas adalah النياحة (meratap) dan bukan hanya sekedar البكاء mengeluarkan air mata. ${ }^{40}$ Ibn Qudâmah berpendapat kata dalam hadits-hadits di atas harus dimaknai tangisan yang tidak

38 Di antaranya Ahmad bin Muhammad al-Qasthallanî, Irsyâd al-Sârî; Syarah Shahîh al-Bukhârî (Beirut: Dâr al-Fikr, t.th), jilid II, hlm. 403

39 Niyâhah menurut al-Nawawi, mengeraskan suara dengan mengulangngulang meratapi kebaikan si mayit. Al-Nawawi, al-Adzkâr (Beirut: Dâr alFikr, t.th), hlm. 125

40 al-Nawâwî, Syarah Shahîh Muslim (Makkah al-Mukarramah: Maktabah Nazzâr Mushtafâ al-Bâz, 2001), cet. II, jilid 4, hlm. 1534 
dibenarkan syari at yaitu meraung dan meratap.41 Adapun menangisi mayit baik sebelum dan sesudah dikubur tanpa mengangkat suara, tanpa mengatakan hal-hal yang seakan-akan menentang takdir Tuhan yang telah ditentukan kepada seluruh hambaNya serta tanpa raungan dan ratapan, hal tersebut tidak mengapa dan boleh menurut pandangan mayoritas ulama. ${ }^{42}$ Senada dengan hal itu al-Khurâfî menjelaskan bahwa tangisan tanpa ratapan diperbolehkan oleh syara', kemudian beliau berdalil dengan tangisan Nabi saw atas kematian kerabat dan sahabat beliau.

Dalam suatu riwayat Umar melarang sayyidah Hafshah ketika meratap menjelang kematiannya, berikut riwayat tersebut:

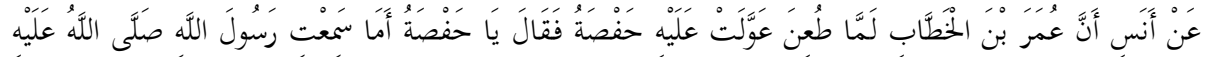

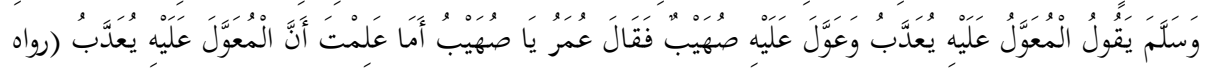

"Dari Anas bahwasanya Umar bin Khatthab ketika (menjelang kematian karena) ditusuk, Hafshah meratapinya. Kemudian Umar berkata, "Wahai Hafshah, apakah engkau tidak mendengar bahwa Rasul saw. bersabda, "Orang yang diratapi akan diadzab". Dan Shuhaib pun meratapi Umar, kemudian Umar berkata, "Wahai Shuhaib, apakah engkau tidak tahu bahwa orang diratapi itu akan diadzab?" (HR. Muslim)

Riwayat yang bercerita tentang ratapan Hafshah dan Shuhaib menjelang meninggalnya Umar di atas diriwayatkan dari jalur Anas dengan redaksi عَوَّ (meratap), dalam riwayat lain (sebagaimana tercantum dalam data) diriwayatkan dari jalur Abdullah bin Umar menggunakan redaksi بحَت (mencakup

${ }^{41}$ Abu Muhammad Muwaffiq al-Dîn Abdullah bin Ahmad bin Muhammad bin Qudâmah, al-Mughnî fî Fiqh al-Imâm Ahmad bin Hanbal al-Syaibânî (Kairo: Hijr li al-Thabâ'ah wa al-Nasyr, 1992), cet. II, jilid III, hlm. 495

42 Ibid. hlm. 487

${ }^{43}$ Muslim, Shahîh Muslim, kitab: al-Janâ'iz, bab: al-Mayyit Yu’addzib bi Bukâ' Ahlih `Alaih, jilid I, hlm. 408 
menangis tanpa dan dengan suara). Riwayat Anas tersebut menegaskan bahwa yang dimaksud dengan بَكَتْ pada riwayat Ibn Umar adalah عََََّتْ (meratap: menangis dengan bersuara). Riwayat Anas juga dapat menjadi penjelas bahwa yang dimaksud dengan tangisan pada keseluruhan hadits riwayat Umar ra. dan Ibn Umar terkait mayit diadzab karena tangisan keluarga atau yang masih hidup adalah ratapan. Bila diperhatikan mayoritas riwayat Umar, terkait dengan tangisan Shuhaib terhadapnya. al-Zain bin al-Munir ${ }^{4}$ menjelaskan, pengingkaran Umar terhadap Shuhaib karena dia menangis dengan suara keras sambil mengatakan "Wahai saudaraku, wahai sahabatku", dan hal ini adalah ratapan. Pada hadits kedua riwayat Muslim di atas diceritakan bahwa ketika Umar tidak sadarkan diri orang yang berada di sekitarnya menangis dengan berteriak, kemudian saat sadar beliau mengutip sabda Nabi saw. tentang adzab bagi mayit yang ditangisi. Menurut penulis, jika orang-orang menangisi Umar dengan meratap, tentu pengingkaran Umar terkait dengan ratapan yang mereka lakukan, meskipun dengan menggunakan bahasa yang lebih umum.

Hadits riwayat Ibn Majah dari jalur Abu Musa al-Asy`ari berikut semakin menguatkan bahwa maksud tangisan pada hadits Umar dan Ibn Umar adalah ratapan:

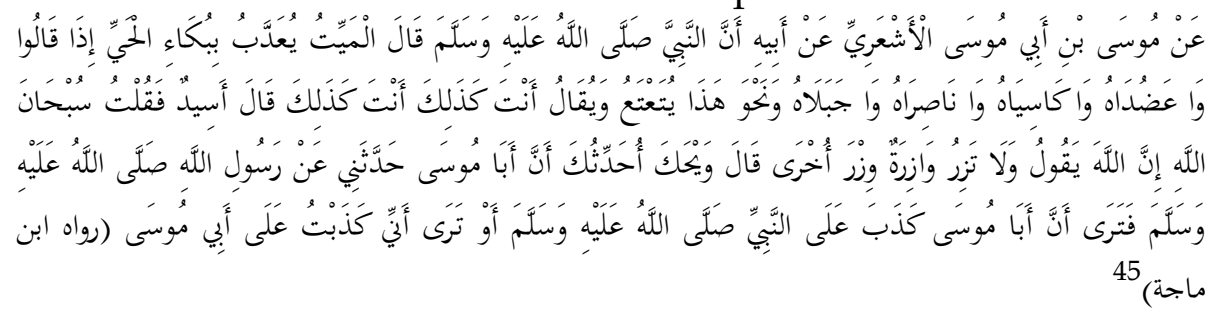

44 Sebagaimana dikutip Ibn Hajar al-Asqalânî, Fath al-Bârî bi Syarh Shahîh alBukhârî (Kairo: Dâr al-Rayyân li al-Turâts, 1990), jilid. III, hlm. 152

${ }^{45}$ Ibn Mâjah, Sunan Ibn M âjah, kitab: Mâ Jâ'a fî al-Janâ'iz, bab: Mâ Jâ'a fî alMayyit Yu`addzib bimâ Nuyiha Alaih, jilid I, hlm. 508 
"Dari Musa bin Abi Musa al-Asy ari, dari ayahnya bahwasanya Nabi saw. bersabda: "Mayit akan diadzab dengan tangisan orang yang masih hidup, jika mereka (orang yang hidup) mengatakan wahai penolong, wahai pemberi pakaian, wahai penderma dan semisal ini dengan berbicara gagap dan dikatakan engkau demikian, engkau demikian". Asid berkata, "Aku katakan Subhanallah, sesungguhnya Allah berfirman, "Sesungguhnya seseorang tidak akan menanggung dosa orang lain". Musa berkata, "Celaka engkau, aku menceritakan padamu bahwa Abu Musa menceritakan padaku dari Rasulullah, apakah engkau menyangka Abu Musa berbohong atas Nabi saw? Atau engkau menyangka aku berbohong atas Abu Musa?" (HR. Ibn Majah)

Al-Bukhari mengatakan bahwa hadits Ibn Umar tentang "mayit diadzab karena tangisan keluarga" bersifat mutlaq, diqayyad oleh hadits Umar dari jalur Ibn Abbas dengan بِعْضِ بُخَاء 46 أَهْله عَلَّيْ bukan seluruh tangisan, dan menurutnya sebagian tangisan tersebut adalah niyâhah (ratapan). ${ }^{47}$

Hal lain yang menguatkan ialah dengan dimasukkannya hadits-hadits tersebut oleh beberapa imam ahli hadits ke dalam bab meratap. Apa yang dilakukan para imam tersebut tentu karena suatu alasan. Imam Nawawi misalnya dalam Riyâdh alShâlihîn memasukkan hadits tersebut ke dalam bab جواز البكاء على (bab Bolehnya Menangisi Mayit Tanpa Meratap). ${ }^{48}$ Abu Daud mencantumkan dalam باب ولاب في النوح (bab tentang Meratap).

${ }^{46}$ Lihat hadits pertama pada kelompok hadits, pertentangan hadits "Mayit diadzab karena tangisa keluarga" dengan al-Qur'an menurut pemahaman Aisyah.

${ }^{47}$ Ibn Hajar, Fath al-Bârî, jilid III, hlm 152

48 Al-Nawâwî, Riyâdh al-Shâlihîn min Kalâm Sayyid al-Mursalîn (Kairo: Dâr Ibn al-Jauzî, 2006), cet. I, hlm. 246

${ }^{49}$ Abu Daud, Sunan Abu Daud, kitab: Janâ'iz, bab: fî al-Nauh, jilid II, hlm. 62 
باب الميت (bab Meratapi Mayit).50 Ibn Majah memasukkan di dalam ماجاء في الميت يعذب بما نيح عليه (bab tentang Mayit Diadzab Karena Ratapan Atasnya). 51

Dengan memaknai kata البكاء dengan النياحة berarti sekedar menangis tidak diharamkan oleh syariat. Dengan begitu, hadits Umar dan Ibn Umar justru saling menguatkan dengan haditshadits yang menjelaskan tangisan Rasul saw.

\section{b. Penyelesaian Dengan Nasakh, Tarjih dan Tawaqquf}

Setelah dikaji, hampir tidak terdapat ulama yang menggunakan penyelesaian selain kompromi pada dua kelompok hadits yang bertentangan. Kecuali beberapa dari mereka yang mengatakan bahwa hadits Umar ra. dan Ibn Umar ra. batil dan tidak dapat dijadikan hujjah karena pertentangannya dengan ayat al-Qur'an, dan hal ini akan penulis kaji pada pembahasan berikutnya.

2. Penyelesaian Pertentangan Antara Hadits Mayit Diadzab Karena Tangisan Keluarga dan Orang yang Hidup dengan Al-Qur'an Menurut Pemahaman Aisyah Menggunakan Metode Mukhtalif Hadits

Diantara hadits-hadits mayit diadzab karena tangisan keluarga atau orang yang masih hidup dan pertentangannya dengan al-Qur'an, menurut pemahaman Aisyah adalah sebagaimana berikut:

Dalam definisi-definisi mukhtalif hadits oleh para ulama qudamâ',52 mereka cenderung mengharuskan pertentangan terjadi antara hadits dengan hadits dan tidak mencakup pertentangan anmtara hadits dengan al-Qur'an dan hadits dengan logika. Namun fakta yang terjadi, dalam karya-karya klasik tentang mukhtalif hadits seperti Ta'wîl Mukhtalif al-Hadîts

\footnotetext{
50 Al-Nasa'i, Sunan al-Nasâ' $\hat{\imath}$, kitab: al-Janâ'iz, bab: al-Niyâhah `Ala al-mayyit, jilid II, hlm. 443-444

${ }^{51}$ Ibn Majah, Sunan Ibn Mâjah, kitab: Mâ Jấa fî al-Janâ'iz, bab: Mâ Jấa fí alMayyit Yu`addzib bi Mâ Nuyih `Alaih, juz I, hlm. 406

${ }^{52}$ Lihat definisi Muktalif Hadits dalam bab II
} 
karya Ibn Qutaibah, hadits yang bertentangan dengan alQur'an, logika maupun fakta dibahas di dalamnya. ${ }^{53}$ Dalam kitab Ikhtilaf al-Hadits karya Syafi i pertentangan hadits-hadits tentang "Mayit Diadzab Karena Tangisan Keluarga atau Orang yang Hidup" dengan al-Qur'an juga dibahas di dalamnya. ${ }^{54}$

Seperti telah ditegaskan di awal, penulis lebih cenderung pada definisi Syaraf al-Qudât. "Hadits yang bertentangan dengan hadits lain, dengan al-Qur'an, logika dan fakta, baik pertentangannya secara zhahir atau hakiki". ${ }^{55}$ Oleh karena itu, pertentangan hadits tentang "Mayit Diadzab Karena Tangisan Keluarga atau Orang yang Hidup" dengan al-Qur'an surah alZumar ayat 7, menurut pemahaman Aisyah, merupakan bagian integral dari pembahasan mukhtalif hadits.

Sebagaimana pertentangan pertama, pertentangan ke dua ini pun memenuhi seluruh syarat-syarat mukhtalif:

a. Pertentangan terjadi dalam satu permasalahan; kedua kelompok sama-sama terkait dengan masalah menangisi jenazah;

b. Pertentangan antara dua hukum atau madlul, dalam kajian ini satu kelompok hadits menjelaskan bahwa mayit diadzab karena tangisan keluarga atasnya, sedangkan hadits yang lain menjelaskan bahwa hal tersebut bertentangan dengan ayat al-Qur'an, karena tidak mungkin seseorang menanggung dosa yang tidak pernah diperbuatnya;

c. Pertentangan dalam satu keadaan. ${ }^{56}$

53 Dalam karyanya, Ibn Qutaibah berusaha menepis anggapan sebagian golongan yang menuduh ulama hadits telah melakukan kecerobohan dalam meriwayatkan hadits yang oleh mereka dianggap bertentangan dengan hadits lainnya, dengan al-Qur'an, pemahaman akal dan bertentangan dengan kemahasucian Allah swt. Ibn Qutaibah, Ta'wil Mukhtalif al-Hadîts, 114

${ }^{54}$ Al-Syafi i, Ikhtilâf al-Hadîts, hlm. 537

55 Pertentangan hakiki disini sifatnya istilahi bukan pada makna yang sebenarnya, lihat teori sub bab Hakikat Pertentangan.

${ }^{56}$ Abd al-Majîd Bairûm, Ikhtilâf Riwâyât al-Hadits, hlm. 167 


\section{Metode Penyelesaian}

\section{a. Penyelesaian Dengan al-Jam`u wa al-Taufiq}

Menurut a-Bukhari, 57 maksud dari hadits "Mayit akan diazab karena tangisan keluarganya" jika meratap merupakan contoh dan kebiasaan dari si mayit saat hidup, sehingga ketika ia meninggal kerabatnya mencontoh apa yang dilakukan si mayit. Si mayit pun tidak melakukan upaya agar kebiasaan jelek tersebut tidak dilakukan ketika dia meninggal. Menurut syara' orang yang memberi contoh kejelekan, dan kemudian kejelekannya diikuti oleh orang lain, maka dia turut berdosa atas apa yang dilakukan orang lain tersebut sebagaimana firman Allah swt:

Hai orang orang yang beriman, peliharalah dirimu dan keluargamu dari api neraka yang bahan bakarnya adalah manusia dan batu; penjaganya malaikat-malaikat yang kasar, keras dan tidak mendurhakai Allah terhadap apa yang diperintahkanNya kepada mereka dan selalu mengerjakan apa yang diperintahkan. (QS, alTahrim: 6)

Dan berdalil pula dengan hadits Nabi saw. berikut ini:

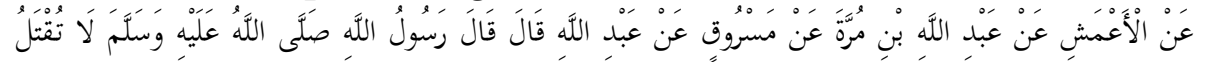

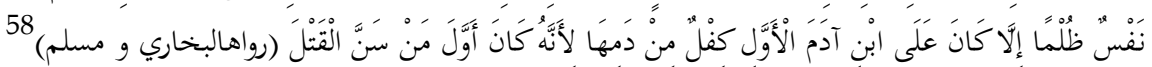
"Telah menceritakan kepada kami Abu Mu'awiyah dari Al A'masy dari Abdullah bin Murrah, dari Masruq, dari Abdullah dia berkata, "Rasulullah shallallahu 'alaihi wasallam bersabda, "Tidaklah setiap kali terjadi pembunuhan terhadap diri seseorang secara zhalim, kecuali putra Adamlah yang pertama kali ikut bertanggung jawab terhadap darahnya, karena dialah manusia pertama yang melakukan pembunuhan". (HR. Bukhari Muslim)

Namun, jika meratap bukan contoh dan kebiasaan si mayit, maka dia tidak akan diadzab karena tangisan atau

57 Sebagaiman dikutip Ibn Hajar, Fath al-Bârî, jilid III, hlm 152-153

${ }^{58}$ Muslim, Shahîh Muslim, kitab: al-Qasâmah wa al-Muhâribîn wa al-Qishâsh wa al-Diyât, bab: Bayân Itsm Man Sann al-Qatl, jilid II, hlm. 100 
ratapan keluarganya, sebagaimana pendapat sayyidah Aisyah, berdalil dengan firman Allah swt.:

Dan seorang yang berdosa tidak akan memikul dosa orang lain. (QS. Al-Zumar: 7)

Ibn Hajar menjelaskan bahwa al-Bukhari hendak mengatakan bahwa seseorang tidak akan diadzab karena perbuatan orang lain, kecuali jika terdapat sebab tertentu, dan sebab tertentu tersebut ialah dengan memberi contoh meratap ketika hidup, dan saat dia meninggal, keluarga dan kerabatnya meniru apa yang telah dia lakukan. Sebagian orang mengkritisi pendapat al-Bukhari dengan mengatakan bahwa secara zhahir yang menerima dampak dosa adalah orang pertama yang memulai bukan yang datang setelahnya. Al-Bukhari menjawab tidak ada yang menafikan dosa bagi orang yang memberi contoh meskipun dia bukan orang pertama yang melakukan. ${ }^{59}$

Senada dengan al-Bukhari meskipun lebih khusus sifatnya, al-Mazni, Ibrahim al-Harbi dan yang lainnya dari penganut madzhab Syafi i mencoba mengkompromikan antara hadits Umar dan hadits Aisyah dengan mengatakan bahwa maksud mayit akan diadzab dengan tangisan keluarganya, jika si mayit berwasiat ketika masih hidup untuk diratapi apabila meninggal dunia. Menurut al-Baghawi60, meratap adalah kebiasaan orang Arab sejak zaman jahiliyah dan terpelihara sampai sekarang bagi sebagian orang. Mereka berwasiat untuk diratapi jika meninggal dunia, hal ini adalah maksiat, apabila orang yang diwasiati melakukannya setelah si pewasiat meninggal maka si pewasiat tersebut berdosa dan bisa jadi dia diadzab karena dosanya tersebut, bukan karena dosa orang lain. Dengan cara kompromi seperti ini, menurutnya hadits Umar tetap shahih dan dapat dijadikan hujjah.

\footnotetext{
59 Ibn Hajar, Fath al-Bârî, hlm. 154.

60 Al-Baghawi, Syarh al-Sunnah (Beirut: Maktabah al-Islâmî, 1990), cet. II, jilid V, hlm. 442-443
} 
Abu Laits al-Samarkandi berpendapat bahwa pendapat di atas adalah pendapat mayoritas ulama, demikian pula menurut al-Nawawi. Ibn al-Wazir al-Yamani menambahkan bahwa al-Bukhari, al-Khithabi, Ibn al-Atsir dalam Syarh Gharîb Hurf al-Mîm, al-Nawawi dalam Riyâdh al-Shâlihîn dan al-Raudhah serta Syarah Muslim juga berpendapat demikian. Menurutnya pendapat ini adalah pendapat yang shahih.. ${ }^{61}$

Hadits riwayat Umar, meskipun menunjukkan seluruh mayit diadzab karena sebagian tangisan, akan tetapi dalil lain membatasi apabila meratap merupakan contoh dan wasiat si mayat ketika masih hidup. Namun jika ratapan bukan kebiasaan dan wasiatnya maka tidak ada tanggungan dosa baginya. ${ }^{62}$ Menurut al-Khithabi63, meratap merupakan kebiasaan di kalangan orang Arab jahiliyah saat itu, dan tetap terpelihara pada beberapa orang setelah kedatangan Islam. Kebiasaan ini tercermin dari beberapa syair:

$$
\text { واذا مت فانعيني بما أنا أهله }
$$

Jika aku mati maka ratapilah aku dengan sepantasnya Dan kesengsaraan dalam hati wahai anak yang dimuliakan 64

Dalil bahwa kebiasaan jahiliyah tetap terpelihara setelah kedatangan Islam adalah hadits berikut:

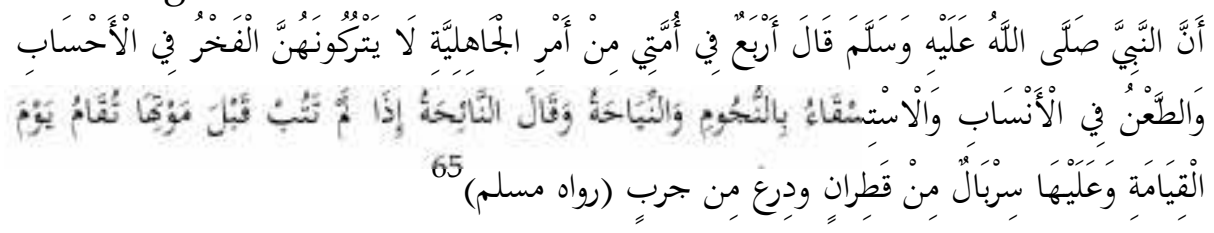

${ }^{61}$ Ibn al-Wazir al-Yamani, al-'Awâshim wa al-Qawâsim 'an Sunnah Abî alQâsim, hlm. 187-188

62 Ibn Hajar, Fath al-Bârî, hlm. 154

${ }^{63}$ Sebagaimana dikutip Ibn al-Wazir al-Yamani, al-`Awâshim wa al-Qawâsim 'an Sunnah Abîal-Qâsim (Beirut: Mu’assasah al-Risâlah Nâsyirûn, 2008), cet. I, jilid III, hlm. 187

${ }^{64}$ Terjemah dilakukan oleh penulis 
"Bahwa Nabi shallallahu 'alaihi wasallam bersabda, "Ada empat perkara jahiliyah yang masih melekat pada umatku dan mereka belum meninggalkannya: Membanggakan kedudukan, mencela nasab (garis keturunan), meminta hujan dengan bintang-bintang, dan niyahah (meratapi mayit)." Dan beliau bersabda, "Orang yang meratapi mayit, jika ia belum bertaubat sebelum ajalnya tiba maka pada hari kiamat ia akan dibangkitkan dengan memakai baju panjang yang berwarna hitam dan memakai tameng dari pedang yang sudah karatan." (HR. Muslim)

Dengan demikian dapat dimengerti bahwa sahabatsahabat yang hidup pada era jahiliyah dan Islam seperti Umar, tidak mengalami kesulitan untuk memahami hadits tentang "Mayit diadzab karena tangisan keluarga" yang ia riwayatkan, meskipun menggunakan redaksi muthlaq.

Pendapat berbeda dikemukakan oleh Ibn Taimiyah ${ }^{66}$, Ibn Qayyim dan al-Thabari, menurut mereka yang dimaksud dengan kata "يُعََّّبُ" adalah merasakan kesakitan dan kepedihan dikarenakan sedih mendengar ratapan kepiluan dan kesedihan hati mereka yang menangisinya. Menurut Ibn Taimiyah, lafazh yang digunakan dalam hadits riwayat Umar bukan يعذب tapi يعاقب dan lafazh عَدَّبُ lebih umum dari عَدَّبُ ,عقاب berarti kesakitan dan عepedihan, menurutnya tidak semua kesakitan merupakan عقاب (siksaan), berdalil dengan hadits Nabi saw.:

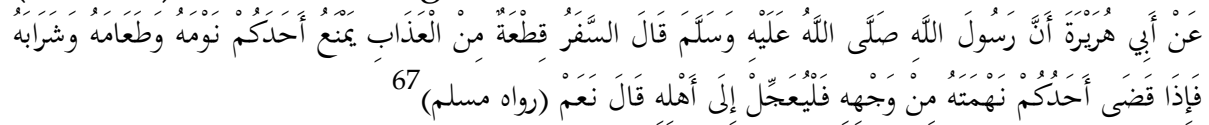

"Dari Abu Hurairah bahwa Rasulullah shallallahu 'alaihi wasallam bersabda, "Perjalanan itu setengah dari siksaan, sebab ia dapat mencegah salah seorang kalian dari tidurnya, makannya dan

${ }^{65}$ Muslim, Shahîh Muslim, kitab: al-Janâ'iz, bab: al-Tasydîd fî al-Niyâhah, jilid I, hlm. 411

${ }^{66}$ Taqî al-Dîn Abû al-Abbâs bin Taimiyah bin Abd al-Halîm bin Taimiyah alHarânî, Majmû al-Fatâwâa (Iskandariyah: Dâr al-Wafâ', 2003), cet. III, jilid XXIV, hlm. 374

${ }^{67}$ Ibid. Kitab: al-Imârah, bab: al-Safar Qith`ah min al-`Adzâb, Jilid II, hlm. 229 
minumnya, oleh karena itu jika urusan kalian telah selesai, segeralah kembali kepada keluargamu." Malik menjawab, "Betul". (HR. Muslim)

Pendapat lain menyebutkan bahwa sayyidah Aisyah dalam riwayatnya tidak menolak hadits shahih yang diriwayatkan Umar dan Ibn Umar, hanya saja ia mengkritik bahwa keduanya lupa atau keliru karena meriwayatkan hadits tidak secara lengkap dan dengan menggunakan redaksi umum yaitu mayit akan diadzab karena tangisan keluarga baik muslim maupun kafir padahal hadits tersebut khusus kepada orang Yahudi. Dan siksaan bagi mayat dalam hadits bukan karena tangisan keluarga dan kerabatnya akan tetapi karena perbuatannya sendiri, sebagaimana yang terdapat dalam riwayat sayyidah Aisyah. 68

\section{b. Cara penyelesaian selain al-Jam u wa al-Taufiq}

Muhammad al-Ghazali menjelaskan bahwa Aisyah telah dengan meyakinkan menolak hadits riwayat Umar dan Ibn Umar, menurutnya apa yang dilakukan Aisyah telah tepat dengan menguji keshahihan suatu hadits dengan al-Qur'an, karena hanya kitab suci inilah yang terbebas dari kesalahan. Dia melanjutkan, anehnya lagi hadits yang telah ditolak Aisyah tersebut masih saja tercantum dalam kitab-kitab shahih, bahkan Ibn Sa'ad dalam Thabaqât al-Kubâ mengulang-ulangnya dengan beberapa jalur sanad. Dalam pembahasannya mengenai pertentangan hadits Aisyah dan Umar, al-Ghazali menjelaskan usaha kompromi yang dilakukan oleh Ibn Taimiyah namun kemudian dibantah karena menurutnya bertentangan dengan al-Qur`an surah Fushilat ayat 30. Di akhir pembahasan dia menjelaskan bahwa apa yang dilakukan tidak bermaksud untuk melemahkan hadits yang masih dapat dishahihkan, namun hendaknya setiap hadits dapat dipahami dalam kerangka

${ }^{68}$ www.ibanim.com diakses tanggal 5 Juni 2014 
makna yang ditunjukkan al-Qur'an, baik secara langsung maupun tidak. ${ }^{69}$

Mengenai masalah ini nampaknya Muhammad alGhazali setuju dengan apa yang dilakukan oleh sayyidah Aisyah, menurutnya hadits-hadits yang bertentangan dengan al-Qur'an secara otomatis tertolak ${ }^{70}$, meskipun dia ingin apa yang dilakukannya tidak dipahami oleh kaum muslim sebagai mendha ifkan hadits yang masih mungkin untuk dishahihkan.

Sebagian $^{71}$ berpendapat, bahwa kritikan Aisyah membuktikan bahwa hadits Umar dan Ibn Umar tentang mayit diadzab karena tangisan keluarga atau orang yang masih hidup, merupakan kebohongan atas Rasulullah karena secara jelas bertentangan dengan al-Qur'an berikut:

Dan seorang yang berdosa tidak akan memikul dosa orang lain. (QS. Al-Zumar: 7)

Dengan pendapat tersebut, secara otomatis hadits-hadits riwayat Umar dan Ibn Umar tidak dapat digunakan sebagai hujjah karena bertentangan dengan dalil yang lebih kuat yaitu al-Qur'an. Dalam kajian mukhtalif hadits, pertentangan hadits dengan al-Qur'an tidak dapat dikategorikan tarjih, karena tarjih mengharuskan kesetaraan dua hadits yang bertentangan dalam kualitas dan kekuatan sanadnya.

Dari sekian banyak pendapat mengenai pertentangan hadits "mayit diadzab karena tangisan keluarganya" dengan hadits tentang "tangisan Nabi saw. atas kematian kerabatnya dengan "alQur'an" menurut pemahaman sayyidah Aisyah", penulis cenderung pada penyelesaian menggunakan cara kompromi. Dalil-dalil yang telah disebutkan menunjukkan bahwa makna hadits Umar dan Ibn Umar adalah mayit diadzab karena ratapan

${ }^{69}$ Muhammad al-Ghazâlî, al-Sunnah al-Nabawiyah bain Ahl al-Figh wa ahl alHadîts, ed. Terjemah oleh Abas M. Basalamah, (Jakarta: Khatulistiwa Pers, 2008), cet. I, hlm. 16-22

70 Tidak syadz adalah salah satu syarat hadits shahih, yaitu: tidak bertentangan dengan hadits yang lebih shahih apalagi al-Qur'an

${ }^{71}$ www.raqcenter.net diakses tanggal 5 Juni 2014 
keluarganya atau orang yang masih hidup jika meratap merupakan kebiasaan, contoh dan wasiat dari si mayit ketika masih hidup. Sedangkan hadits riwayat Aisyah tetap berlaku sesuai porsinya apabila tangisan keluarga bukan contoh dan kebiasaan si mayit, lebih-lebih jika si mayit telah melarang dan mewanti-wanti keluarganya untuk tidak diratapi ketika masih hidup.

Pertentangan hadits Umar dan Ibn Umar tentang menangis mayit dengan al-Qur'an bukanlah ketetapan syara' namun merupakan pemahaman pribadi sayyidah Aisyah. Pernyataannya bahwa Ibn Umar telah keliru dalam meriwayatkan, akan menjadi logis jika Ibn Umar infarada (bersendiri) dalam meriwayatkannya, faktanya hadits-hadits ini diriwayatkan pula oleh Umar dan Abu Musa al-Asy`ari. Jika Umar dan Ibn Umar dapat keliru maka hal yang sama dapat pula terjadi pada pemahaman sayyidah Aisyah. Mengenai penjelasan bahwa sabab al-wurud hadits menangisi mayit berkaitan dengan perempuan Yahudi kemungkinan merupakan ijtihad beliau pula, mengingat banyak versi tentangnya. Di satu riwayat disebutkan bahwa Nabi saw. lewat di hadapan seorang perempuan Yahudi yang telah meninggal dan ditangisi oleh keluarganya, kemudian Rasul bersabda, "Mereka menangis padahal dia sedang diadzab dalam kuburnya" ${ }^{72}$ Pada riwayat lain Nabi saw. bersabda, "Sesungguhnya orang kafir akan ditambah adzabnya oleh Allah swt. karena tangisan keluarganya". ${ }^{73}$ Sedangkan di tempat berbeda Nabi saw. bersabda, "Sesungguhnya mayit diadzab karena kesalahan dan dosanya".

Umar bin Khatthab adalah orang yang hidup di dua era, yaitu era jahiliyah dan era masyarakat Islam, dengan kebiasaan meratap dan berwasiat untuk diratapi saat itu maka bukan hal

72 Muslim, Shahîh Muslim, kitab: al-Janâ'iz, bab: al-Mayyit Yu`addzib bi Bukâ' Ahlih, jilid I, hlm. 411

${ }^{73}$ al-Bukhârî, Shahîh al-Bukhârî, kitab: al-Janâ'iz, bab: al-Mayyit Yu ‘addzib bi Bikâ' Ahlih `Alaih, jilid I, hlm. 409 
yang sulit baginya untuk memahami maksud dari sabda Nabi saw. yang ia riwayatkan meskipun dengan redaksi yang bersifat muthlaq. Berbeda dengan sahabat-sahabat yang lahir di era Islam atau lahir pada era jahiliyah namun tumbuh besar pada era Islam. Bahkan Ibn Umar yang terlahir tiga tahun setelah kenabian tersebut dalam riwayatnya tentang menangisi mayit terlihat berbeda dengan riwayat ayahnya, bisa jadi perbedaan tersebut dikarenakan perbedaan dalam pemahaman hadits meskipun sama-sama meriwayatkan. Dalam riwayat Umar disebutkan mayit diadzab karena sebagian tangisan sedangkan riwayat Ibn Umar dimuthlaqkan, dalam riwayat Umar disebutkan bahwa pengingkarannya terhadap orang yang menangisi karena mereka tidak sekedar menangis tapi meratap dan berteriak, sedangkan dalam hadits Ibn Umar sebab pengingkarannya karena tangisan pada kematian putri nabi, tanpa dijelaskan jenis tangisannya.

Tentang kompromi Ibn Taimiyah, bahwa yang dimaksud adzab bagi mayit yang ditangisi bukanlah siksaan melainkan si mayit merasakan kepiluan dan kesakitan mendengar ratapan kesedihan mereka yang menangisinya, secara zhahir bertentangan dengan sabda Nabi saw bahwa siksaan tersebut benar-benar terjadi:

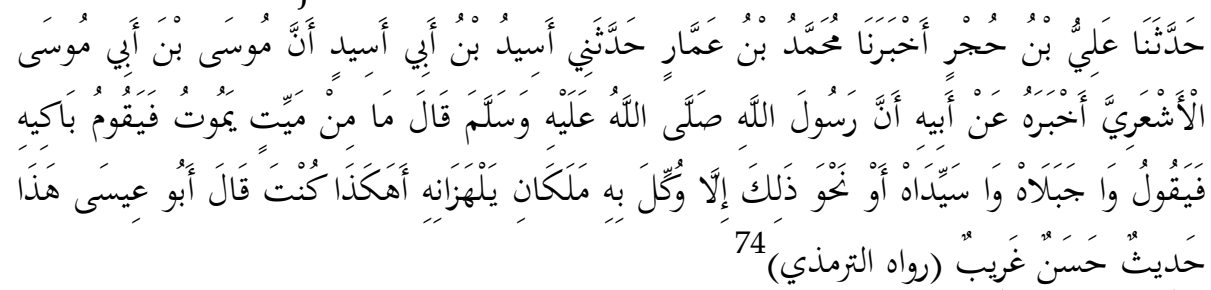

Telah menceritakan kepada kami Ali bin Hujr, telah mengabarkan kepada kami Muhammad bin 'Ammar, telah menceritakan kepadaku 'Asid bin Abu 'Asid bahwa Musa bin Abu Musa Al Asy'ari mengabarinya, dari bapaknya bahwa Rasulullah shallallahu 'alaihi

74 Al-Tirmidzî, Sunan al-Tirmidzî, kitab: al-Janâ'iz, bab: Mâ Jâ'a fî Karâhiyah al-Bukâ' `Alâ al-Mayyit, jild III, hlm. 326 
wasallam bersabda, "Tidaklah seseorang meninggal, lalu orang-orang berdiri meratapinya dengan berkata, 'Wa jaballah wa sayyidah (Aduhai celakanya aku, Aduhai sialnya aku! dan sejenisnya), niscaya akan dikirim dua orang Malaikat untuk memukulinya sambil menghardiknya dengan berkata, "Betulkah demikian keadaanmu (di dunia)?". Abu 'Isa berkata, "Ini merupakan hadits hasan gharib." (HR. Tirmidzi)

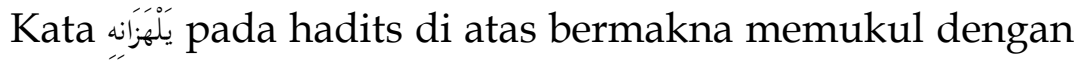
cara mengepalkan seluruh jari tangan (menonjok). ${ }^{75}$ Pendapat terakhir bahwa Aisyah tidak menolak hadits Ibn Umar, hanya saja beliau mengkritisi keduanya dikarenakan tidak meriwayatkan hadits secara sempurna, tidak sejalan dengan zhahir hadits Aisyah yang menolak riwayat keduanya karena bertentangan dengan al-Qur'an, ia mengatakan, "Cukup bagi kalian al-Qur'an". Jika demikian yang terjadi, tentu redaksinya akan berbeda dan tidak mengindikasikan pertentangannya dengan al-Qur'an. Sebagaimana telah dijelaskan, bahwa sabab al-wurud hadits menangisi mayit merupakan ijtihad Aisyah, sehingga dapat disimpulkan bahwa hadits Umar dan Ibn Umar merupakan hadits yang berbeda dengan yang disampaikan Aisyah. Sehingga adzab bagi mayit yang memberi contoh dan berwasiat untuk diratapi bukanlah khusus diperuntukkan bagi orang kafir tapi berlaku baik bagi orang kafir atau orang muslim.

\section{Penutup}

Dari paparan sebelumnya dapat disimpulkan bahwa:

1. Dari sekian pendapat ulama tentang definisi ilmu Mukhtalif Hadits, penulis lebih cenderung dengan pendapat Syaraf alQudhat bahwa ilmu Mukhtalif Hadits ialah "ilmu yang membahas hadits yang bertentangan dengan hadits lain, dengan al-Qur'an, logika dan fakta, baik pertentangannya 75 Ibrâhîm Mushtafâ, Ahmad al-Ziyât, Hâmid Abd al-Qâdir, Mu`jam al-Wasîth
(Kairo, Majma` al-Lughah al-`Arabiyah, 1998), jilid II, hlm. 601 
secara zhahir atau hakiki". Definisi tersebut hemat penulis lebih mencakup keseluruhan ilmu Mukhtalif Hadits baik praktek atau teori. Meskipun mayoritas ulama mengharuskan pertentangan dalam mukhtalif hadits harus terjadi antara hadits dengan hadits lainnnya, faktanya dalam karya ulama tentang muktalif hadits pertentangan hadits dengan logika, fakta dan ayat al-Qur'an juga dibahas di dalamnya.

Secara asal, tidak terdapat pertentangan di antara dalil-dalil syara', baik hadits dengan hadits atau hadits dengan alQur'an, selama hadits tersebut merupakan hadits shahih dalam penyandarannya kepada Nabi saw. kecuali satu hadits merupakan nâsikh shârih bagi hadits yang lainnya. Hal itu dikarenakan seluruh nash syara' baik al-Qur'an maupun hadits terbebas dari perbedaan dan pertentangan, mengingat sumber dari nash-nash tersebut satu yaitu Allah swt., mustahil hukum yang bersumber dariNya bertentangan antara satu dengan yang lain.

Pertentangan antara hadits dengan hadits lainnya tidak dapat terwujud kecuali telah memenuhi beberapa hal berikut: pertama; Pertentangan terjadi dalam satu konteks permasalahan, jika pertentangan pada dua konteks yang berbeda maka keduanya tidak dapat dianggap bertentangan. Kedua; Pertentangan antara dua hukum atau madlûl, hukum yang terkandung dalam dua hadits yang saling bertentangan salah satunya menunjukkan keharaman dan yang lain menunjukkan kehalalan. Ketiga; Kedua hadits yang bertentangan sama dalam kualitas. Keempat; Pertentangan terjadi pada satu keadaan.

Imam Syafi i dan mayoritas ahli Hadits berpendapat bahwa muktalif hadits dapat diselesaikan dengan metode berikut: pertama; Al-Jam`u wa al-Taufiq, yaitu mencari titik pertentangan dan berusaha untuk mengkompromikannya. Kedua; Nasakh yaitu melacak dalil mana yang menghapus dan mana yang dihapus. Ketiga; al-Tarjîh, yaitu mengambil salah 
satu dalil dan meninggalkan yang lain karena keyakinan bahwa salah satu dalil terdapat kekeliruan di dalamnya. Keempat; al-Tawaqquf/ al-Tasâqith; yaitu tidak mengambil kedua dalil yang bertentangan, dengan syarat tidak dapat dipecahkan dengan seluruh bentuk penyelesaian baik kompromi, nasakh maupun tarjih.

2. Terdapat dua pertentangan pada hadits-hadits tentang menangisi mayit. Pertama; pertentangan hadits Umar bin Khatthab dan Ibn Umar yang menjelaskan tentang "mayit diadzab karena tangisan keluarga", dengan hadits-hadits yang menunjukkan bahwa "Rasulullah saw. menangis atas meninggalnya keluarga dan sahabat beliau". Kedua; Pertentangan antara hadits "Mayit Diadzab Karena Taingisan Keluarga dan Orang yang Hidup" dengan "Al-Qur'an" menurut pemahaman Aisyah, karena seseorang diadzab sebab dosa yang diperbuat oarang lain menurutnya bertentangan dengan ayat "Dan seorang yang berdosa tidak akan memikul dosa orang lain". (QS. Al-Zumar: 7). Kedua pertentangan di atas memenuhi syaratsyarat pertentangan dalam ilmu Mukhtalif Hadits sehingga layak untuk dikaji dengan perspektif mukhtalif hadits.

3. Pertentangan hadits Umar bin Khatthab dan Ibn Umar yang menjelaskan tentang "mayit diadzab karena tangisan keluarga", dengan hadits-hadits yang menunjukkan bahwa "Rasulullah saw. menangis atas meninggalnya keluarga dan sahabat beliau" dapat diselesaikan dengan cara kompromi, yaitu dengan memaknai "menangis" البكاء dalam hadits "mayit diadzab karena tangisan keluarga" sebagai "meratap". Dengan kompromi tersebut, maka tidak terdapat lagi pertentangan antara hadits Umar dan Ibn Umar dengan hadits tentang tangisan "Nabi saw. atas kematian kerabat dan sahabatnya". Maka sekedar menangis berurai air tanpa meratap tetap diperbolehkan, bahkan di salah satu hadits Beliau bersabda, "Allah tidak mengadzab karena tangisan air mata tetapi Allah swt. mengadzab karena ini (beliau mengisyaratkan ke lisannya)". Sedangkan pertentangan "menangisi mayit" dengan "al- 
Qur'an" menurut Aisyah, dapat pula diselesaikan dengan cara kompromi, yaitu dengan memaknai hadits "mayit diadzab dengan tangisan keluarga" jika meratap merupakan kebiasaan, contoh dan wasiat dari si mayit ketika masih hidup. Dengan demikian makna hadits riwayat Umar bin Khatthab dan Ibn Umar berikut:

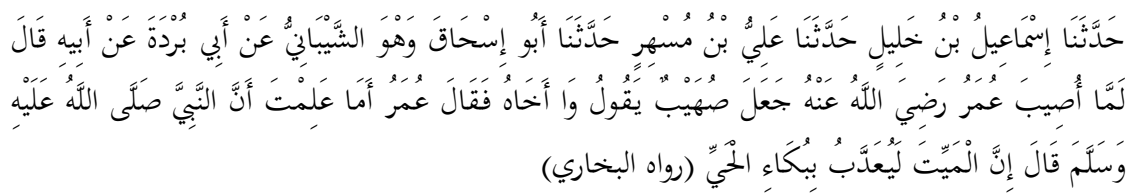

Artinya: "mayit diadzab karena ratapan keluarganya atau orang yang masih hidup, jika meratap merupakan kebiasaan, contoh dan wasiat dari si mayit ketika masih hidup".

Hadits Aisyah pun tetap berlaku sesuai porsinya, yaitu mayit tidak menanggung dosa dan diadzab apabila tangisan keluarga bukan contoh dan kebiasaan si mayit, lebih-lebih jika si mayit telah melarang dan mewanti-wanti keluarganya untuk tidak diratapi ketika masih hidup.

\section{Daftar Pustaka:}

Asfahânî al-, Raghib, al-Mufradât fí Gharîb al-Qur'ân (Beirut: Dâr al-Ma rifah, 2010)

‘Asqalânî al-, Abû al-Fadhl Ahmad bin Ali bin Muhammad bin Ahmad bin Hajar, Nukhbat al-Fikr fî Mushtalah Ahl al-Atsar (Beirut: Dâr Ihyâ' al-Turâts al-'Arabî, t.th) Ibn Hajar, Fath al-Bârî bi Syarh Shahîh al-Bukhârî (Kairo: Dâr al-Rayyân li al-Turâts, 1990)

Azdî al-, Abu Ja`far Ahmad bin Muhammad bin Salâmah alThahâwî, Musykil al-Atsâr (Beirut: Mu`assasah al-Risalah, t.th.)

Baghawi al-, Syarh al-Sunnah (Beirut: Maktabah al-Islâmî, 1990), cet. II

Bairûm, Abd al-Majîd, Ikhtilâf Riwâyât al-Hadits wa Atsaruh fî Ikhtilâf al-Fuqahâ' (Amman: al-Jami'ah al-Urduniyah, 1990) 
Baqầ $̂$, Ali Nâif, al-Ijtihâd fì 'Ilm al-Hadits wa Atsaruh 'alâ al-Fiqh al-Islâmî (Beirut: Dâr al-Basyâ'ir al-Islâmiyah, 1998)

Bukhâri al-, Abu Abdillah Muhammad bin Ismầil, Shahîh alBukhârî (Beirut: Dâr al-Fikr, t.th.)

Ghazâlî al-, Muhammad, al-Sunnah al-Nabawiyah bain Ahl al-Figh wa ahl al-Hadits, ed. Terjemah oleh Abas M. Basalamah, (Jakarta: Khatulistiwa Pers, 2008), cet. I

Hâdî al-, Abd al-Muhdî Abd., al-Madkhal ila al-Sunnah alNabawiyah (Kairo: Dâr al-I tishâm, 2000), cet. II

Hafîzhî, Hakîmah, Mukhtalif Hadits (al-Jazair: Wazârah al-Ta 'lîm al-`Alî, 2010)

Hajjaj al-, Muslim bin, Shahîh Muslim (Beirut: Dâr al-Fikr, 1988), cet. I

Harânî al-, Taqî al-Dîn Abû al-Abbâs bin Taimiyah bin Abd alHalîm bin Taimiyah, Majmû̀ al-Fatâwâa (Iskandariyah: Dâr al-Wafâ', 2003), cet. III

Hasan, Khâlid Ramadhân, Mưjam Ushûl Figh (al-Raudhah: 1998), cet. Ke I

M. Subhan dan M. Sudrajat, Dasar-Dasar Penelitian Ilmiyah (Bandung: Pustaka Setia, 2005)

Mâjah, Ibn, Sunan Ibn Mâjah (Beirut: Dâr al-Fikr, t.th.)

Manzhûr, Ibn, Lisân al- 'Arab (Beirut: Dâr Shâdir, t.th.), cet, I

Naisâbûrî al-, Abi al-Husain Muslim bin al-Hajjâj al-Qusyairî, Shahîh Muslim, (Beirut: Dâr al-Fikr, 1988), cet. I al-Hâkim Abi Abdillah Muhammad bin Abdillah al-Hâfizh, Ma 'rifah 'Ulûm al-Hadîts (Beirut: Dâr Ihyâ' al'Ulûm, t.th), cet. I

Nasa'I al-, Sunan al-Nasa'I (Kairo: Dar al-Hadits, 1421 H/2010 $\mathrm{M})$

Sunan al-Nasa'î bi Syarh al-Suyûthî wa al-Sindiy (Kairo: Dâr al-Hadîts, $1421 \mathrm{H} / 2000 \mathrm{M}$ )

Nawawi al-, al-Adzkâr (Beirut: Dâr al-Fikr, t.th)

Ibn Syaraf, Taqrîb 'Ulûm al-Hadîts (dengan catatan kaki Tadrîb al-Râwî) (al-Madinah: al-Maktabah al'Ilmiyah, 1972), cet. II 
Riyâdh al-Shâlihîn min Kalâm Sayyid al-Mursalîn (Kairo: Dâr Ibn al-Jauzî, 2006), cet. I Syarah Shahîh Muslim (Makkah al-Mukarramah: Maktabah Nazzâr Mushtafâ al-Bâz, 2001), cet. II

Qâdir al-, Ibrâhîm Mushtafâ, Ahmad al-Ziyât, Hâmid Abd, Mu jam al-Wasîth (Kairo, Majma`al-Lughah al-`Arabiyah, 1998)

Qârî al-, Mula Nûr al-Dîn Abû al-Hasan, Syarh Nukhbah al-Fikr (Beirut; Dâr al-Arqâm, t.th), cet. I

Qasthallanî al-, Ahmad bin Muhammad, Irsyâd al-Sârî; Syarah Shahîh al-Bukhârî (Beirut: Dâr al-Fikr, t.th)

Qudâmah bin, Abu Muhammad Muwaffiq al-Dîn Abdullah bin Ahmad bin Muhammad, al-Mughnî fi Figh al-Imâm Ahmad bin Hanbal al-Syaibânî (Kairo: Hijr li al-Thabâ'ah wa al-Nasyr, 1992), cet. II

Qudhât al-, Syaraf, 'Ilm Mukhtalif Hadits; Ushîluh wa Qawầiduh (Amman: al-Jami'ah al-'Urduniyah, 2001)

Qutaibah, Muhammad bin Abdullah bin Muslim, Ta'wîl Mukhtalif al-Hadîts (Beirut: Dâr al-Isyrâq, 1989), cet. I

Sausuwah al-, Abd al-Majîd Muhammad Isma`îl, Manhâj alTaufì wa al-Tarjîh bain Mukhtalif al-Hadîts wa Atsaruh fì Figh al-Islâmî (Kairo: Jami ah al-Qâhirah, 1992)

Shalih Subhi, 'Ulum al-Hadits wa Mushthalahuh, ed. terjemah oleh Tim Pustaka Firdaus (Jakarta: Pustaka Firdaus, 2009), cet. XIII

Shana'ânî al-, Muhammad Isma'îl al-Kahlânî, Subul al-Salâm (Beirut: Dâr al-Fikr, t.th.)

Shiddieqy ash-, Teungku Muhammad Hasbi, Sejarah dan Pengantar Ilmu Hadits (Semarang: PT. Pustaka Rizki, 1997), cet. I

Shidiq, Sapiudin, Ushul Fiqh (Jakarta: Kencana Prenada Media Group, 2011), cet. I

Sijistânî al-, Abi Daud Sulaiman bin Asy'as, Sunan Ab̂̂ Dâud (Beirut: Dâr al-Fikr, 1410 H/1990 M), cet. I 
Supiana, Prof., Metodologi Studi Islam (Jakarta: Direktorat Jenderal Pendidikan Agama Islam, 2012), cet. Ke-2

Suyûthî al-, Abd al-Rahmân bin Abî Bakar, Tadrîb al-Râwî̀ fî̀ Syarh Taqrîb al-Nawâwî̀ (Riyâdh: Maktabah Riyâdh alHadîtsah, t.th.)

Syafi'I al-, Ikhtilâf al-Hadits (Beirut: Muassasah al-Kutub alTsaqâfiyah, 1985), cet. I al-Risalah (Beirut: Dâr al-Kutub al-'Ilmiyah, t.th.)

Syahrazûrî al-, Abî 'Amr Utsmân bin Abd al-Rahmân, Muqaddimah Ibn Shalâh (Iskandariyah: Dâr Ibn Khaldûn, t.th)

Thahhân, Mahmûd, Taisîr Musthalâh al-Hadîits (Beirut: Dâr alFikr, t.th),

Tirmidzî al-, Abî 'Îsâ Muhammad bin 'Îsâ bin Saurah, Sunan alTirmidzi (Beirut: Dâr al-Fikr, t.th.)

Yamani al-, Ibn al-Wazir, al-`Awâshim wa al-Qawâsim 'an Sunnah Ab̂̀ al-Qâsim (Beirut: Mu’assasah al-Risâlah Nâsyirûn, 2008), cet. I

Yango, Huzaimah Tahido, Pengantar Perbandingan Madzhab (Jakarta: Logos Wacana Ilmu, 1997)

Zain al-, Dr. Samith 'Athif, al-Mu'amalat, al-Bayyinat, al-'Uqobat (Beirut: Dar al-Kitab, 2009), cet. Ke-2 Nizham al-Islam (Beirut: Dar al-Kitab, 1989), cet. Ke-1

Zuhri, Muh., Hadis Nabi, Telaah Historis dan Metodologis (Yogyakarta: PT. Tiara Wacana, t.th)

www.ibanim.com

www.raqcenter.net

http://kamusbahasaindonesia.org/kontroversi

www.kangmuz.wordpress.com

WwW.studipemikiranislam.wordpress.com

www.tukarpendapat.files.wordpress.com 